\title{
Partitioning of elements in a entrained flow IGCC plant: Influence of selected operational conditions
}

\author{
O. Font ,X. Querol , M. Izquierdo , E. Alvarez , N. Moreno , S. Diez , R. Álvarez-Rodríguez , \\ C. Clemente-Jul , P. Coca , F. Garcia-Peña \\ Institute of Environmental Assessment and Water Research (IDAA-CSIC), Jordi Girona 18-26, E-08034 Barcetona, Spain \\ Mining School, Technical University of Madrid, 21 Ríps Rosas Street, 28003 Madrid. Spain \\ ELCOGAS S.A., Carretera de Calzada a Puertollano km 27, 13500 Puertollano. Ciudad Real, Spain \\ Instituto de Recursos Naturales y Agrobiologia de Salamanca (IRNASA), Cordel de Merinas, 42-54, 37008 Salomanca. Spain
}

Keywords:

Fly ash

Trace elements

Partitioning

IGCC

\begin{abstract}
A B S T R A C T
The partitioning of trace elements and the influence of the feed conditions (50:50 coal/pet-coke feed blend and limestone addition) was investigated in this study. To this end feed fuel, fly ash and slag samples were collected under different operational conditions at the $335 \mathrm{MW}$ Puertollano IGCC power plant (Spain) and subsequently analysed. The partitioning of elements in this IGCC plant may be summarised as follows: (a) high volatile elements (70->99\% in gas phase): $\mathrm{Hg}, \mathrm{Br}, \mathrm{l}, \mathrm{Cl}$ and $\mathrm{S}$; (b) moderately volatile elements (up to $40 \%$ in gas phase and $\geqslant 60 \%$ in fly ash): As, Sb, Se, B, F, Cd, Tl, Zn and Sn; (c) elements with high condensation potential: (>90\% in fly ash): $\mathrm{Pb}, \mathrm{Ge}, \mathrm{Ga}$ and $\mathrm{Bi}$; (d) elements enriched similarly in fly ash and slag 30-60\% in fly ash: $\mathrm{Cu}, \mathrm{W},(\mathrm{P}), \mathrm{Mo}, \mathrm{Ni}$ and $\mathrm{Na}$; and (e) low volatile elements (>70\% in slag): $\mathrm{Cs}, \mathrm{Rb}$ $\mathrm{Co}_{0}, \mathrm{~K}, \mathrm{Cr}, \mathrm{V}, \mathrm{Nb}, \mathrm{Be}, \mathrm{Hf}, \mathrm{Ta}, \mathrm{Fe}, \mathrm{U}, \mathrm{Ti}, \mathrm{Al}, \mathrm{Si}, \mathrm{Y}, \mathrm{Sr}, \mathrm{Th}, \mathrm{Zr}, \mathrm{Mg}, \mathrm{Ba}, \mathrm{Mn}, \mathrm{REEs}, \mathrm{Ca}$ and Li. The volatility of As, Sb. and $\mathrm{Tl}$ and the slagging of $\mathrm{S}, \mathrm{B}, \mathrm{Cl}, \mathrm{Cd}$ and low volatile elements are highly influenced by the fuel geochemistry and limestone dosages, respectively.
\end{abstract}

\section{Introduction}

Studies on the partitioning of trace elements in commercial IGCC plants are scarce [1-4] and most of them based on experiments carried out at laboratory and pilot plant scale [5-9], and on modelling of the gas phase [10,11].

The implementation of IGCC plants at industrial scale is expected to growth in the forthcoming years. Among the three most common types of gasification technologies (entrained flow, fixed bed and fluidized bed) the entrained flow gasification systems have been the choice of industry for current IGCC systems [12]. These three types of gasification technologies differ in a number of operational conditions including feed system of coal, the temperature and pressure and the coal size input [12], the highest gasification temperature $\left(1200-1600^{\circ} \mathrm{C}\right)$ and pressure $(25-40 \mathrm{bar})$ and the lowest feed coal size $(0.1 \mathrm{~mm})$ being attained in entrained flow gasifiers. The fixed bed gasifier is characterised by having the largest size of feed coal (3-30 mm) and the lowest temperatures (400$1150^{\circ} \mathrm{C}$ ), with a wide range of pressure $(10-100 \mathrm{bar})$, while fluidized bed gasifiers reach intermediate temperatures $\left(800-1050^{\circ} \mathrm{C}\right)$, pressures (10-25 bar) and feed coal sizes (1-5 mm). Furthermore, these gasification technologies have different ash removal systems and temperature. The different operational parameters showed above may result in a different behaviour and fate of elements depending on the gasification technology applied. Consequently, studies on the fate of trace elements in gasification systems are thus being necessary to progress on trace pollutants abatement in IGCC plants.

In pulverised coal combustion (PCC) plants trace elements are partitioned among the slag/bottom ash, fly ash or flue gas according to their volatile behaviour, their mode of occurrence in coal and the operational parameters of the PCC plants [13-20]. The classification of elements proposed by Meij [14] has been commonly used as a reference for subsequent partitioning studies. This classification is based on the enrichment factors (EFs) of the elements in bottom ash and fly ash during coal combustion classified in three groups: Class I includes the non-volatile elements (Al, Ca, Cs, Fe, $\mathrm{Hf}, \mathrm{Mg}, \mathrm{Sc}, \mathrm{Si}, \mathrm{Sr}, \mathrm{Th}, \mathrm{Ti}$ and REEs); Class II comprises the volatile elements condensing on ash particles. These elements are in increasing condensation potential or enrichment factor (EF) in fly ash: $\mathrm{Ba}, \mathrm{Cr}, \mathrm{Mn}, \mathrm{Na}$ and $\mathrm{Rb}$ (Class IIc); Be, Co, Cu, Ni, U, V and $\mathrm{W}$ (Class [lb), and As, Cd, Ge, Mo, Pb, Sb, Tl and Zn (Class Ila). The Class [I] comprises the highly volatile elements (B, Br, C, Cl, F, Hg, I, N, S and $\mathrm{Se}$ ), which remain totally or partially in gas phase at fly ash removal temperatures. 
As stated above due the relatively new and scarce implementation of IGCC at commercial scale, few studies on the partitioning of elements have been elaborated. Studies on partitioning of elements in fixed bed gasifiers [2-4] have revealed a similar behaviour of a number of elements in coal combustion. These studies reported $\mathrm{Hg}$ as highly volatile element and $\mathrm{Se}, \mathrm{Cd}, \mathrm{Pb}$. As (in decreasing order) as volatile elements during gasification with subsequent condensation on ash particles. Copper, Mo, $\mathrm{Ni}$ and $\mathrm{Zn}$ showed a relatively low volatilisation and condensation while $\mathrm{Ba}, \mathrm{Co}, \mathrm{Cr}$, Mn and V were found as non-volatile elements. The first studies on partitioning of elements in entrained flow gasifiers [8] were based on combining experimental data and thermodynamic equilibrium calculations, and reported a significant volatile fraction of $\mathrm{As}, \mathrm{Se}, \mathrm{Sb}, \mathrm{Pb}$ and $\mathrm{Hg}$ (remaining in the vapour phase at 500 $600^{\circ} \mathrm{C}$ ), while $\mathrm{Cd}, \mathrm{Cr}, \mathrm{Co}, \mathrm{Mn}, \mathrm{Ni}, \mathrm{U}$ and $\mathrm{Th}$ are relatively non-volatile. Other studies on this topic [10], reported the formation of Fe$\mathrm{Mn}$ sulphide and $\mathrm{Na}-\mathrm{K}$ chloride species at the highest cooling temperatures ( 900 and $800^{\circ} \mathrm{C}$, respectively) and subsequent condensation of $\mathrm{Zn}, \mathrm{Pb}$ and $\mathrm{As}$ sulphide species at temperature ranges of $810-220,520$ and $380^{\circ} \mathrm{C}$, respectively. The modelling studies carried by Diaz-Somoano and Martinez-Tarazona [11] for a number of trace elements in entrained flow gasifiers, at different gas atmospheres and pressures and at subsequent cooling temperatures, predicted relatively high volatile fractions of $\mathrm{Sb}, \mathrm{As}, \mathrm{Cd}, \mathrm{Pb}, \mathrm{Zn}$ and $\mathrm{Ni}$ at high $\mathrm{Cl}$ gasification atmosphere and high condensation of these elements (mainly as sulphide species) at low $\mathrm{Cl}$ and high $\mathrm{H}_{2} \mathrm{~S}$ gasification atmospheres and at fly ash removal temperatures between 200 and $300^{\circ} \mathrm{C}$

Despite the restrictions of the thermodynamic calculations, the above predicted behaviour, speciation and condensation temperatures for a number of elements in entrained flow gasifiers are in relatively accordance with those obtained from samples deposited on the cooling system of the commercial scale Puertollano IGCC power plant $[21,22]$. Studies in this plant have revealed the formation of Fe-Ni-V sulphide species segregated on the fly ash particles at high temperatures $\left(\sim 1200^{\circ} \mathrm{C}\right)$, partially reacting with gaseous $\mathrm{As}$ and $\mathrm{Sb}$ to form $\mathrm{Fe}-\mathrm{Ni}$ arsenide-antimonide species at $800^{\circ} \mathrm{C}$ and the subsequent condensation of gaseous sulphide species, with the prevalence of galena ( $\mathrm{PbS}$ ) at $520-750^{\circ} \mathrm{C}$, sphalerite ( $\left.\mathrm{ZnS}\right)$ and Ge species at $520-470^{\circ} \mathrm{C}$ and wurtzite (ZnS) at $300-400^{\circ} \mathrm{C}$.

In this study the partitioning of elements during the gasification is evaluated for a number of solid streams representative of different feed fuel characteristics and operational conditions in the Puertollano JGCC plant. This plant is fed with a mixture of a local high volatile bituminous coal rich in metals and semi-metals [23] and pet-coke, supplied by a nearby oil refinery. Limestone is added $(2-4 \%)$ to the feed fuel blend as a fluxing agent. The gasification is carried out in a pressurised entrained flow gasifier working under slagging conditions and at $1200-1600^{\circ} \mathrm{C}$ and 25 bars. The influence of a number of operational conditions (the slag/fly ash ratio, the flue gas cooling, co-gasification of coal and pet-coke and the addition of limestone as a fluxing agent) on the partitioning of the elements among the IGCC by-products and flue gas is evaluated.

\section{Materials and methods}

For the study of the partitioning of trace elements among flue gas, slag and fly ash, four set of samples were selected from the operational period 2001-2005 of the Puertollano IGCC plant. Each sample set containing simultaneously collected samples of coal, pet-coke, limestone, feed fuel blend, slag and fly ash. During this sampling period the Puertollano IGCC plant has been operated with close to 50:50 coal/pet-coke blends and 2.3-2.7\% limestone addition (Table 1). In this power plant, the fuel, following pulveri-
Table 1

Sampling date, limestone dose and coalfpet-coke ratio of the feed blends for the set of samples collected.

\begin{tabular}{llll}
\hline Sample set & Sampling date & limestone (\%) & Coal/pet-coke \\
\hline$\# 1$ & $23 / 03 / 01$ & 2.3 & $49.6 / 47.2$ \\
$\# 2$ & $25 / 05 / 05$ & 2.7 & $44.2 / 52.9$ \\
$\# 3$ & $08 / 06 / 05$ & 2.6 & $43.8 / 53.2$ \\
$\# 4$ & $20 / 10 / 05$ & 2.5 & $46.0 / 51.5$ \\
\hline
\end{tabular}

sation (down to $<100 \mu \mathrm{m}$ ) and drying, is pressurised (to 25 bars) and carried to the gasifier in an inert environment of $\mathrm{N}_{2}$. The pulverised fuel enters the gasifier through four burners set at $90^{\circ} \mathrm{C}$ and is mixed with $\mathrm{O}_{2}$ (85\% purity). The gasification process is carried out at $1200-1600^{\circ} \mathrm{C}$ and 25 bars. The slagging properties of the gasifier results in a high production (90\%) of molten ash removed from the bottom of the gasifier in liquid form. The slag then enters a water bath, where is cooled and crushed. The remaining $10 \%$ of the ash is entrained by the gas. The fuel particles undergo the pyrolysis and gasification processes. The gases produced are first cooled down to $800^{\circ} \mathrm{C}$ when leaving the gasifier with a recycled quenched gas flow $\left(235^{\circ} \mathrm{C}\right)$. When leaving the gasifier, the gas is successively cooled down to 400 and $265^{\circ} \mathrm{C}$ in high and medium pressure boilers, respectively. In the pressure boilers high and intermediate pressure steam ( 127 and 35 bars, respectively) is produced, which is sent to the combined cycle heat steam regenerator boiler. After re-heating the steam is expanded into the steam turbine. The ashes are removed from the gas at $265^{\circ} \mathrm{C}$ by means of ceramic candle filters. By this process the dust content of the gas is reduced to $<3 \mathrm{mg} / \mathrm{Nm}^{3}$. The gas, free of particles, is carried to the gas cleaning and desulphurisation unit. Halides and other impurities $\left(\mathrm{HCl}, \mathrm{HF}, \mathrm{NH}_{3}, \mathrm{HCN}\right.$ and $\mathrm{H}_{2} \mathrm{~S}$ ) are removed from the gas using a Venturi scrubber with $\mathrm{NaOH}$ as a neutraliser agent. The sulphur is removed by conversion of $\mathrm{H}_{2} \mathrm{~S}$ to elemental sulphur. Then, the gas is expanded in a $200 \mathrm{MW}$ gas turbine. A $135 \mathrm{MW}$ steam turbine burns the steam generated in the heat recovery steam generator.

The main chemical and mineralogical features of the feed fuel, slag and fly ash were investigated according to the following procedures:

- The moisture and ash content were determined at 105 and $750^{\circ} \mathrm{C}$ following the ASTM recommendations.

- The content of major and trace elements were determined by means of Inductively Coupled Plasma Atomic Emission Spectrometry (ICP-AES) and Inductively Coupled Plasma Mass Spectrometry (ICP-MS). A special two step sample digestion method for the analysis of potentially volatile elements in coals and fly ash devised by Querol et al. [15] was used to dissolve the samples prior to the analysis.

- Due the loss of silicon fluoride during the evaporation of HF from in the above sample digestion procedure, the HF acid digestion described by Thompson and Walsh [24] was used to determine the silica content in the bulk solid samples.

- The content of $\mathrm{Hg}$ was determined by Gold Amalgam Atomic Absorption Spectrometry (GA-AAS, AMMA-LECO) directly on solid samples.

- The $\mathrm{Cl}$ contents were determined by the Eschka method [25], followed by an ion chromatographic analysis of the water-leached residues.

- The determination of $\mathrm{F}$ was performed following the method described by Sager [26], and analysed by fluoride sensitive electrode.

- The contents of B were determined using the method described by Pougnet and Orren [27] and the resulting extracts analysed by ICP-AES. 
- The amorphous and crystalline phases of the samples were determined by X-ray powder diffraction using a BRUCKER D5005 powder diffractometer with a graphite monochromator, $\mathrm{NaI}(\mathrm{Tl})$ detector, and $\mathrm{Cu} \mathrm{K} \alpha$ radiation.

To quantify the partitioning among flue gas, fly ash and slag, Alnormalised EFs for major and trace elements in fly ash/feed fuel (EFfly ash) and slag/feed fuel (EF slag) as well as fly ash + slag/feed fuel or mass balance (MB) have been calculated considering Al as a non-volatile element during gasification using the following normalisation formulas proposed by Gordon and Zoller [28] and Querol et al. [15], (a) EFfly ash - [Ci - fly ash/CAl - fly ash]/[Ci - blend/ CAl - blend $]$, (b) EF slag = [Ci - slag/CAl - slag $] /[\mathrm{Ci}-$ blend/CA $]-$ blend $]$ and (c) $\mathrm{MB}=$ (EF fly ash $*$ fly ash production $)+$ (EF slag *slag production), were $\mathrm{Ci}$ is the concentration of a given trace element and $\mathrm{CAl}$ is the concentration of aluminium in the gasification by-product considered and in the fed fuel blend. The mass balance is obtained by normalising the EFs with the percentage produced of each by-product. The coal and coal-coke blend has been considered as the input stream and flue gas, fly ash and slag as the output streams. Using the above normalisation system, elements entiched in fly ash (by volatilisation followed by condensation from flue gas) will yield an enrichment factor (EFfly ash) $>1$. Low volatile elements will not be enriched in fly ash, and will yield in an enrichment factor (EF slag) $\geqslant 1$. Low EFs for both fly ash and slag point to volatilisation processes with very minor condensation from flue gas. The MB, obtained from the adjusted EFs with the fly ash and slag production allows determining the volatile fraction of each element present in the raw gas. Mass balances $<1$ points to a partial gaseous phase in the raw gas for a given trace element. It is worth mentioning that an analytical error about $10-15 \%$ must be assumed in the determination derived from the method employed [29].

\section{Results and discussion}

\subsection{Feed fuel characterisation and source of trace elements}

The feed coal of Puertollano IGCC plant is characterised by low moisture (2.6-6.8\%) and very high ash content (46-52\%, Table 2$)$. The ash content of the feed coal samples is higher than the range (11-36\%) reported by Alastuey et al. [23] for coal bench characterisation, probably due to different coal seams being currently worked and because during mining some internal and external partings are also mixed with coal. The $C$ contents range from $36 \%$ to $41 \%$ and $\mathrm{H}$ and $\mathrm{N}$ contents from $2.4 \%$ to $3 \%$ and from $0.5 \%$ to $0.9 \%$, respectively (Table 2 ). The major mineral phases detected on the Puertollano feed coal samples are quartz, kaolinite, illite, siderite, ferric dolomite, dolomite and pyrite, in agreement with the mineralogy reported by Alastuey et al. [23]. The content of major and trace element determined in the feed coal samples from the sample sets (Tables 2 and 3) generally fall in the ranges obtained for the Puertollano coal by Alastuey et al. [23]. In specific samples, certain trace elements, such as $\mathrm{As}, \mathrm{Ba}, \mathrm{Bi}, \mathrm{Ni}$, U or $\mathrm{V}$, slightly exceed the highest values reported by these authors. The contents of $\mathrm{Cl}$ $(819-1424 \mathrm{mg} / \mathrm{kg})$ and $\mathrm{F}(206-939 \mathrm{mg} / \mathrm{kg})$ are reasonably high (six and three times higher than the coal worldwide values (180 and $88 \mathrm{mg} / \mathrm{kg}$ for $\mathrm{Cl}$ and $\mathrm{F}$, respectively) reported by Yudovich and Ketris [30]. The high contents of $\mathrm{Cl}$ and probably also that of F of the Puertollano coal may be due to their accumulation in coals in a post-sedimentary digenetic process from leaching of the interlayered volcanic tuffs [31]. Among feed coal samples significant variations occur for $\mathrm{S}(0.4-1.0 \%)$, As $(26-122 \mathrm{mg} / \mathrm{kg})$, Ge (9$31 \mathrm{mg} / \mathrm{kg})$. Ni (37-139 $\mathrm{mg} / \mathrm{kg})$. Pb $(79-259 \mathrm{mg} / \mathrm{kg})$, V (66$265 \mathrm{mg} / \mathrm{kg})$, and $\mathrm{Zn}(260-515 \mathrm{mg} / \mathrm{kg})$, such ranges probably being related to inter-seam or intra-seam geochemical variations repoited by Alastuey et al. [23].

The pet-coke gasified at the Puertollano IGCC plant, is characterised by very low moisture (0.4-3.5\%) and ash content $(0.2-$ $2.9 \%$, Table 2 ) and by a very high $C$ content $(87.2-89.3 \%$, Table 2$)$. With the exception of the pet-coke sample from set \#3, the S content is high (3.4-4.2\% S, Table 3). Also pet-coke shows a high content of $\mathrm{Cl}(584-2013 \mathrm{mg} / \mathrm{kg}$ ) and occasionally of $\mathrm{F}$ ( up to $631 \mathrm{mg} / \mathrm{kg}$ in set \#4, Table 3 ). With regard to metal content (Table 3 ), the petcoke shows high contents of $V(586-1236 \mathrm{mg} / \mathrm{kg})$, Ni (199$301 \mathrm{mg} / \mathrm{kg})$ and moderately high content of Mo $(9.3-19.8 \mathrm{mg} / \mathrm{kg})$ and $\mathrm{Zn}(<0.01-116 \mathrm{mg} / \mathrm{kg}$ ). The results are in the range obtained for the pet-coke gasified at the Puertollano IGCC plant Puertollano [32].

The limestone used as fluxing aging has a $\mathrm{C}$ content close to $12 \%$ (Table 2). Since no organic $\mathrm{C}$ occurs (100\% of $\mathrm{C}$ is extracted with $\mathrm{HCl}$ $5 \mathrm{~N}$ ), the bulk $\mathrm{C}$ values are equivalent to a $\mathrm{CO}_{3}$ content of $58.9 \%$, $59.6 \%$, and $55.1 \%$. Besides calcite, traces of Fe-dolomite, quartz and clay minerals (such as montmorillonite) were also detected by XRD. The ratio calcite/dolomite is very high, ranging from 229 to 253 by weight. Taking into account this ratio, it can be assumed that $>99 \%$ of Ca occurs as calcite, but when coupled with the geochemistry of the limestone samples (Tables 2 and 3) the calcite content ranges from $85 \%$ to $>99 \%$. The limestone samples are also

Table 2

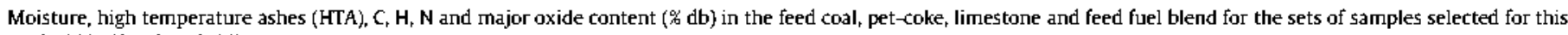
study (\#1, \#2, \#3 and \#4).

\begin{tabular}{|c|c|c|c|c|c|c|c|c|c|c|c|c|c|c|c|}
\hline \multirow[b]{2}{*}{ Set } & \multicolumn{4}{|l|}{ Coal } & \multicolumn{4}{|c|}{ Pet-coke } & \multicolumn{3}{|c|}{ limestone } & \multicolumn{4}{|c|}{ Feed fuel blend } \\
\hline & \#1 & $\# 2$ & \#3 & \#4 & $\# 1$ & $\# 2$ & $\# 3$ & $\# 4$ & $\# 2$ & \#3 & $\# 4$ & \#1 & $\# 2$ & $\# 3$ & $\# 4$ \\
\hline Moisture & 2.6 & 6.8 & 5.3 & 6.3 & 0.6 & 3.5 & 0.4 & 0.8 & 0.2 & 0.2 & 0.2 & 1.5 & 0.8 & 0.7 & 1.5 \\
\hline HTA & 46 & 48 & 52 & 49 & 2.9 & 0.3 & 0.2 & 2.3 & - & - & - & 28 & 24 & 23 & 26 \\
\hline C & 41 & 36 & 35 & 41 & 87 & 87 & 89 & 87 & 11.9 & 12.0 & 11.7 & 63 & 64 & 64 & 65 \\
\hline H & 2.5 & 2.4 & 2.7 & 3.0 & 3.1 & 3.9 & 3.9 & 3.7 & 0.07 & 0.09 & 0.05 & 2.8 & 3.2 & 3.3 & 3.3 \\
\hline $\mathbf{N}$ & 0.5 & 0.8 & 0.9 & 0.9 & 2.3 & 1.8 & 1.6 & 1.9 & $<0.01$ & $<0.01$ & $<0.01$ & 1.4 & 1.4 & 1.2 & 1.4 \\
\hline $\mathrm{Al}_{2} \mathrm{O}_{3}$ & 11.4 & 11.4 & 12.4 & 11.1 & 0.1 & 0.1 & 0.1 & 0.05 & 0.8 & 1.0 & 0.6 & 5.7 & 5.6 & 5.7 & 4.8 \\
\hline $\mathrm{CaO}$ & 0.4 & 0.5 & 1.0 & 0.3 & 0.03 & 0.07 & 0.03 & 0.03 & 48 & 52 & 55 & 1.3 & 0.9 & 1.0 & 1.4 \\
\hline $\mathrm{Fe}_{2} \mathrm{O}_{3}$ & 2.5 & 2.5 & 2.7 & 3.4 & 0.03 & 0.04 & 0.02 & 0.01 & 0.3 & 0.7 & 0.3 & 1.3 & 1.3 & 1.5 & 1.4 \\
\hline $\mathrm{K}_{2} \mathrm{O}$ & 1.2 & 1.1 & 1.1 & 1.1 & 0.01 & $<0.01$ & $<0.01$ & $<0.01$ & 0.1 & 0.1 & 0.1 & 0.6 & 0.5 & 0.6 & 0.5 \\
\hline $\mathrm{MgO}$ & 0.4 & 0.3 & 0.5 & 0.4 & 0.01 & 0.01 & 0.01 & $<0.01$ & 0.6 & 0.6 & 0.5 & 0.2 & 0.2 & 0.2 & 0.2 \\
\hline Mno & 0.03 & 0.02 & 0.02 & 0.03 & $<0.01$ & 0.001 & $<0.01$ & $<0.01$ & 0.01 & $<0.01$ & 0.01 & 0.01 & 0.01 & 0.01 & 0.01 \\
\hline $\mathrm{Na}_{2} \mathrm{O}$ & 0.02 & 0.1 & 0.3 & 0.8 & $<0.01$ & 0.03 & $<0.01$ & 0.04 & 0.01 & 0.03 & 0.01 & 0.01 & $<0.01$ & 0.01 & 0.1 \\
\hline $\mathrm{P}_{2} \mathrm{O}_{5}$ & 0.03 & 0.04 & 0.5 & 0.1 & $<0.01$ & 0.01 & $<0.01$ & $<0.01$ & 0.01 & $<0.01$ & $<0.01$ & 0.02 & $<0.01$ & 0.01 & 0.03 \\
\hline $\mathrm{SiO}_{2}$ & 24 & 24 & 27 & 25 & 0.2 & 0.3 & $<0.01$ & 0.7 & 1.5 & 1.4 & 2.3 & 12.1 & 10.3 & 9.6 & 11.1 \\
\hline$S$ & 0.9 & 0.4 & 0.5 & 1.0 & 3.4 & 42 & 0.1 & 3.9 & 0.04 & 02 & 0.04 & 2.6 & 1.0 & 1.1 & 2.4 \\
\hline $\mathrm{TiO}_{2}$ & 0.3 & 0.3 & 0.4 & 0.3 & $<0.01$ & $<0.01$ & $<0.01$ & $<0.01$ & 0.03 & 0.1 & 0.02 & 0.2 & 0.1 & 0.2 & 0.1 \\
\hline
\end{tabular}


Table 3

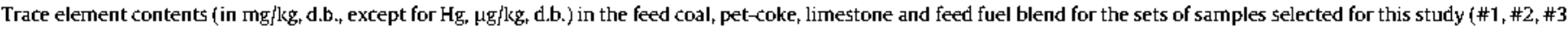
and \#4).

\begin{tabular}{|c|c|c|c|c|c|c|c|c|c|c|c|c|c|c|c|}
\hline \multirow[b]{2}{*}{ Set } & \multicolumn{4}{|l|}{ Coal } & \multicolumn{4}{|l|}{ Pet-coke } & \multicolumn{3}{|c|}{ Limestone } & \multicolumn{4}{|c|}{ Feed fuel blend } \\
\hline & $\# 1$ & $\# 2$ & $\# 3$ & $\# 4$ & $\# 1$ & $\# 2$ & $\# 3$ & $\# 4$ & $\# 2$ & $\# 3$ & $\# 4$ & $\# 1$ & $\# 2$ & $\# 3$ & $\# 4$ \\
\hline $\mathrm{Cl}$ & 819 & 1424 & 894 & 1024 & 2013 & 1447 & 584 & 865 & 2017 & 2017 & $<500$ & 1714 & 1363 & 1237 & 300 \\
\hline B & 45 & 31 & 52 & 47 & 14 & 11 & 22 & 20 & 21 & 24 & 33 & 29 & 26 & 29 & 33 \\
\hline$F$ & 232 & 206 & 269 & 934 & 23 & 36 & 27 & 631 & 89 & 111 & 625 & 125 & 122 & 124 & 717 \\
\hline $\mathrm{Br}$ & - & 10.5 & 10.8 & 9.5 & - & 3.5 & 22 & 1.8 & 0.1 & - & - & - & 7 & 6.5 & 5.7 \\
\hline 1 & - & 1.4 & 7.2 & 6.1 & - & 1.5 & 2.7 & 2.3 & 3.3 & - & - & - & 1.5 & 5 & 4.2 \\
\hline As & 61 & 66 & 26 & 122 & 1.5 & 1.4 & 0.7 & 2.8 & 3.3 & 14.4 & 2.1 & 31 & 33 & 22 & 22 \\
\hline $\mathrm{Ba}$ & 209 & 293 & 238 & 309 & 2.0 & 5.7 & 3.2 & 4.1 & 18 & 26 & 21 & 135 & 144 & 140 & 125 \\
\hline $\mathrm{Be}$ & 3.0 & 5.4 & 4.2 & 3.8 & 0.4 & $<0.01$ & 0.1 & $<0.01$ & 0.4 & 0.4 & 0.1 & 2.7 & 2.1 & 1.9 & 1.7 \\
\hline $\mathrm{Bi}$ & 2.4 & $<0.01$ & 1.6 & 1.2 & 2.1 & $<0,01$ & $<0.01$ & 0.1 & $<0.01$ & 0.1 & 0.1 & 0.4 & 0.1 & 1.1 & 0.8 \\
\hline cd & 2.8 & 1.0 & 1.6 & 0.8 & 1.9 & $<0,01$ & 0.03 & 0.1 & $<0.01$ & 0.1 & 0.1 & 0.6 & 0.6 & 0.8 & 0.7 \\
\hline Co & 16 & 18 & 15 & 14 & 0.7 & 2.4 & 0.8 & 0.8 & 5.0 & 1.9 & 1.3 & 6.1 & 9.4 & 8.2 & 6.4 \\
\hline $\mathrm{Cr}$ & 61 & 50 & 48 & 43 & 10.9 & 7.2 & 32 & 5.0 & 10.3 & 7.8 & 5.7 & 26 & 28 & 28 & 24 \\
\hline Cs & 45 & 29 & 21 & 31 & $<0.01$ & $<0.01$ & 0.2 & 0.05 & $<0.01$ & 0.8 & 0.4 & 20 & 14 & 15 & 13 \\
\hline Cu & 44 & 48 & 44 & 56 & 1.8 & 4.6 & 1.7 & 1.9 & 0.8 & 4.4 & 2.9 & 16 & 21 & 20 & 17 \\
\hline $\mathrm{Ga}$ & 9 & 16 & 18 & 16 & 0.3 & 0.9 & 1.0 & 0.7 & 1.3 & 1.5 & 0.9 & 4.9 & 9.1 & 10.5 & 8.1 \\
\hline $\mathrm{Ge}$ & 16 & 9 & 12 & 31 & $<0.01$ & $<0,01$ & 0.4 & 1.1 & $<0.01$ & 0.4 & 0.2 & 6.6 & 8.1 & 8.3 & 11.3 \\
\hline $\mathrm{Hf}$ & 3.8 & 4.0 & 8.7 & 11.3 & 1.4 & 2.5 & 0.02 & 0.1 & 2.3 & 1.0 & 0.4 & 1.7 & 1.6 & 5.1 & 3.8 \\
\hline $\mathrm{Hg}$ & 523 & 571 & 404 & 400 & 9 & 42 & 15 & 6.9 & 3.8 & 7.9 & 2.2 & 0.2 & 0.3 & 0.2 & 0.2 \\
\hline la & 30 & 24 & 23 & 24 & 0.2 & 0.6 & 0.3 & 0.1 & 1.8 & 2.4 & 1.6 & 18 & 12 & 14 & 11 \\
\hline li & 60 & 89 & 70 & 88 & 0.6 & $<0.01$ & 0.4 & 3.0 & 3.9 & 4.5 & 3.0 & 38 & 44 & 35 & 40 \\
\hline Mo & 7.5 & 7.9 & 1.8 & 5.1 & 11.8 & 19.8 & 8.8 & 9.3 & 0.9 & $<0.01$ & $<0.01$ & 7.6 & 11.9 & 7.5 & 5.8 \\
\hline $\mathrm{Nb}$ & 9.3 & 17.1 & 7.8 & 7.5 & $<0.01$ & $<0.01$ & $<0.01$ & 0.02 & $<0.01$ & 0.8 & 0.7 & 5.0 & 5.1 & 4.5 & 3.7 \\
\hline $\mathrm{Ni}$ & 37 & 139 & 38 & 41 & 219 & 301 & 199 & 285 & 34 & 9.5 & 6.2 & 123 & 216 & 128 & 135 \\
\hline $\mathrm{Pb}$ & 250 & 160 & 188 & 79 & 2.2 & 3.3 & 1.4 & 1.4 & 3.3 & 3.6 & 1.9 & 140 & 95 & 117 & 120 \\
\hline $\mathbf{R b}$ & 61 & 51 & 61 & 53 & 0.2 & $<0.01$ & 0.2 & 0.2 & 4.0 & 6.5 & 3.9 & 29 & 27 & 35 & 25 \\
\hline$S b$ & 40 & 42 & 21 & 48 & 5.6 & $<0.01$ & 0.1 & 1.6 & $<0.01$ & 0.3 & 0.4 & 20 & 20 & 15 & 24 \\
\hline Sc & 7.7 & 8.0 & 44 & 80 & 0.4 & 1.0 & 0.7 & $<0.01$ & 1.4 & 5.6 & 1.8 & 4.5 & 3.9 & 22.5 & 15.8 \\
\hline Se & $<0.01$ & $<0.01$ & 1.4 & $<0.01$ & $<0.01$ & 1.3 & $<0.01$ & $<0.01$ & 0.4 & 1.1 & $<0.01$ & 3.0 & 0.7 & 2.9 & 2.4 \\
\hline sn & 2.9 & 4.6 & 3.8 & 3.4 & 0.3 & 1.1 & $<0.01$ & 0.2 & 1.1 & 0.3 & 0.4 & 1.9 & 2.8 & 2.2 & 1.8 \\
\hline $\mathrm{Sr}$ & 44 & 51 & 65 & 50 & 0.6 & 1.8 & 1.4 & 1.5 & 126 & 113 & 142 & 28 & 29 & 35 & 30 \\
\hline $\mathrm{Ta}$ & 4.6 & 17.2 & 1.0 & 2.1 & 1.7 & 2.7 & 0.02 & 0.04 & 5.9 & 0.1 & 0.05 & 1.5 & 2.5 & 0.4 & 0.6 \\
\hline Th & 4.2 & 9.1 & 112 & 11.7 & 1.1 & 6.3 & 0.03 & 0.03 & 7.6 & 0.8 & 0.5 & 7.2 & 5.5 & 5.6 & 4.3 \\
\hline $\mathrm{TI}$ & 1.2 & 4.1 & 0.8 & 1.0 & 1.0 & 3.9 & $<0.01$ & 0.01 & 4.6 & 0.1 & 0.03 & 0.5 & 2.5 & 0.6 & 0.4 \\
\hline Tm & 0.5 & 1.1 & 0.4 & 0.3 & 0.2 & 0.7 & $<0.01$ & 0.01 & 0.8 & 0.03 & 0.02 & 3.6 & 5.4 & 2.0 & 1.7 \\
\hline $\mathrm{U}$ & 2.6 & 13.6 & 4.0 & 3.6 & 1.9 & 6.8 & 0.02 & 0.04 & 8.3 & 0.4 & 0.4 & 855 & 734 & 415 & 558 \\
\hline v & 72 & 265 & 66 & 72 & 849 & 1237 & 586 & 1235 & 1.3 & 15.1 & 5.8 & 3.5 & 7.1 & 1.9 & 2.2 \\
\hline$w$ & 12.3 & 21.7 & 2.6 & 10.0 & 2.3 & 10.8 & 0.04 & 1.8 & 9.2 & 0.1 & 0.8 & 11.5 & 8.7 & 12.7 & 10.3 \\
\hline Y & 21 & 19 & 25 & 23 & $<0.01$ & 0.9 & 0.1 & 0.1 & 2.1 & 2.7 & 1.6 & 130 & 281 & 246 & 240 \\
\hline $\mathrm{Zn}$ & 271 & 458 & 515 & 260 & $<0.01$ & 116 & 27 & 29 & 12 & 18 & 11.4 & 48 & 30 & 39 & 29 \\
\hline $\mathrm{Zr}$ & 52 & 50 & 59 & 93 & $<0.01$ & 3.2 & 0.02 & 1.1 & 4.1 & 8.1 & 3.4 & 27 & 12 & 8 & 21 \\
\hline
\end{tabular}

characterised by relatively high contents of $\mathrm{Cl}$ (up to $2017 \mathrm{mg} / \mathrm{kg}$ ) and $\mathrm{F}(89-625 \mathrm{mg} / \mathrm{kg}$ ). These elements may occur in the apatite framework, a mineral commonly found in limestone, but other $\mathrm{Cl}$ and $F$ species should occur in limestone taking into account that apatite is not present in XRD detectable levels $(<1 \%$ wt of apatite, if any).

In accordance with the contents determined for coal, pet-coke and limestone, the feed fuel blend is characterised by a low moisture $(0.7-1.5 \%)$, high ash (23-28\%) and high $C$ contents $(63-35 \%$, Table 2). Despite the dilution effect of the addition of pet-coke. the feed fuel still contains relatively high contents of $S(1.0-2.6 \%)$ and the trace elements enriched in coal and pet-coke. The content of $\mathrm{Cl}, \mathrm{F}, \mathrm{I}, \mathrm{Bi}, \mathrm{Ga}, \mathrm{Hf}, \mathrm{Mo}, \mathrm{Ni}, \mathrm{Sc}, \mathrm{Se}, \mathrm{Tl}, \mathrm{U}, \mathrm{V}, \mathrm{W}, \mathrm{Zn}$ and $\mathrm{Zr}$ show significant variations among set of samples (by a factor of 2-5), whereas the variations found for other trace elements in coal and pet-coke are masked by the dilution effect (Tables 2 and 3).

As regards the relative contributions of coal, pet-coke and limestone to the major and trace elements in the feed fuel blend (Fig. 1), coal is the main source (>80\%) for most elements ( $\mathrm{Al}, \mathrm{Fe}$, $\mathrm{K}, \mathrm{Mg}, \mathrm{Na}, \mathrm{Si}, \mathrm{Ti}, \mathrm{As}, \mathrm{Ba}, \mathrm{Be}, \mathrm{Co}, \mathrm{Cs}, \mathrm{Cu}, \mathrm{Cr}, \mathrm{Ga}, \mathrm{Ge}, \mathrm{Hg}, \mathrm{Li}, \mathrm{Nb}, \mathrm{Pb}$, $\mathrm{Rb}, \mathrm{Sb}, \mathrm{Sc}, \mathrm{Sn}, \mathrm{Sr}, \mathrm{Y}, \mathrm{Zn}$ and $\mathrm{Zr}$ ). With the exception of $\mathrm{Mg}$ and $\mathrm{Sr}$, the remaining proportion of these elements is provided by petcoke. Due to the high $\mathrm{V}$ and Ni contents and the high proportion of pet-coke in the feed fuel blends, this secondary fuel is the main source of $\mathrm{Ni}(68-87 \%), \mathrm{V}(82-94 \%)$ and $\mathrm{Mo}(65-83 \%)$. Commonly, a high proportion of $S$ is sourced from pet-coke (79-91\%), although in some cases it can derive mainly from coal ( $84 \%$ set \#3). As expected, $\mathrm{Ca}$ is supplied mainly from the limestone (72-91\%). Even with low amounts of limestone with respect coal and pet-coke, this material provides significant proportions of $\mathrm{Mg}(6-8 \%)$ and $\mathrm{Sr}$ (8$12 \%$ ) to the feed fuel blend. Coal is usually the main source of $B$ and $F$ (around 70 and $59-89 \%$, respectively), but a significant fraction, around $30 \%$ of $\mathrm{B}$ and $9-39 \%$ of $\mathrm{F}$ is supplied by pet-coke. Chlorine is supplied in similar proportions by coal (48-56\%) and petcoke (37-49\%), respectively. A number of elements show a relatively high variability in the proportions supplied by coal and pet-coke. In this regard, although coal supply up to $>95 \%$ of $P$, $\mathrm{Mn}, \mathrm{Bi}, \mathrm{Hf}, \mathrm{Ta}, \mathrm{Th}, \mathrm{Tl}, \mathrm{U}$ and $\mathrm{W}$, pet-coke can also supply significant amounts of these elements (21-49\%). The highest proportions supplied by pet-coke of $\mathrm{P}, \mathrm{Bi}, \mathrm{Hf}, \mathrm{Ta}$, Th, Tl, $\mathrm{U}$ and $\mathrm{W}$ occurs for set \#2 while that of Mn for set \#3. The source of Se also shows a high variability, being supplied in high proportions (75\%) by coal in sets \#3 and \#4 and by pet-coke in set \#2 (68\%).

\subsection{Slag and fly ash characterisation}

The slag is mainly made up of an amorphous Al-Si glass ( $>99 \%$ ). Anorthite $\left(\mathrm{CaAl} \mathrm{Si}_{2} \mathrm{SO}_{8}\right)$, clinoferrosilite $\left(\mathrm{FeSiO}_{3}\right)$, orthoferrosilite $\left((\mathrm{Fe}, \mathrm{Mg}) \mathrm{SiO}_{3}\right)$ and $\mathrm{Al}$-chromite $\left.\mathrm{Fe}(\mathrm{Al}, \mathrm{Cr})_{2} \mathrm{O}_{4}\right)$ may crystallize from the melt if cooling is slow enough [22] The $\mathrm{SiO}_{2}$ and $\mathrm{Al}_{2} \mathrm{O}_{3}$ contents 




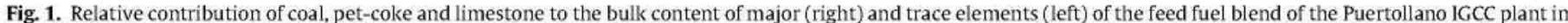
three feed sample sets.

in the slag range from $50.2 \%$ to $59.2 \%$ and from $23.0 \%$ to $24.5 \%$, respectively (Table 4 ). The slag samples also contains minor amounts of $\mathrm{Fe}_{2} \mathrm{O}_{3}(4.5-7.4 \%), \mathrm{CaO}(4.9-7.5 \%)$ and $\mathrm{SO}_{3}(1.0-2.4 \%)$ contents. Furthermore, high contents of a number of minor and trace elements, such as V (1681-3527 mg/kg), Ni (192-828 mg/ $\mathrm{kg}), \mathrm{Cl}(200-1392 \mathrm{mg} / \mathrm{kg}$ ) and occasionally in $\mathrm{F}(548 \mathrm{mg} / \mathrm{kg}$ in sample S-\#13) were also determined (Table 4).

As regards Puertollano IGCC fly ash samples, the speciation of a number of trace elements are similar than reported in previous studies $[21,22,32-34]$. These studies revealed that IGCC fly ash samples are mainly made up of an amorphous $\mathrm{Al}-\mathrm{Si}$ glass The crystalline phases galena ( $\mathrm{PbS})$, sphalerite and wurtzite $(\mathrm{ZnS})$ and phyrrhotite $\left(\mathrm{Fe}_{1-x} \mathrm{~S}\right)$, as well as nickeline (NiAs), condensed from reducing vapour species in cooling flue gas, are present in XRD detectable levels ( $>1 \% \mathrm{wt}$ ). Table 4 shows the concentrations of major and trace elements in the IGCC fly ash samples. The concentration of $\mathrm{Zn}, \mathrm{Pb}, \mathrm{Ge}, \mathrm{As}, \mathrm{Sb}, \mathrm{Cd}, \mathrm{Cu}, \mathrm{Sn}, \mathrm{V}, \mathrm{Ni}$, and $\mathrm{Mo}$, in fly ash are around one order of magnitude higher than the highest concentrations of fly ash from PCC European plants while $\mathrm{SiO}_{2}$ concentrations are close to maximum concentrations observed in 23 European combustion fly ash [35]. As shown in Table 5, a large number of elements ( $\mathrm{Pb}, \mathrm{Ge}, \mathrm{Ga}$ and $\mathrm{Bi} \mathrm{As}, \mathrm{Br}, \mathrm{Sb}, \mathrm{B}, \mathrm{F}, \mathrm{Cd}, \mathrm{Tl}, \mathrm{Se}$, $\mathrm{Zn}, \mathrm{Sn}$ ) display extremely high fly ash/slag ratios when compared with usually obtained in coal combustion $[14,15]$. The mean values for the four set of samples are in the range of 9-568. This is due to the high slag production with respect fly ash $(90: 10)$ and the high occurrence of condensation processes during gas cooling [21]. Other elements typically highly volatile $(\mathrm{S}, \mathrm{Hg}, \mathrm{I}$, and $\mathrm{Cl}$ ) show mean fly ash/slag ratios in the 0.7-2.1 range. Copper, $\mathrm{W}, \mathrm{Mo}, \mathrm{Ni}$ and $\mathrm{Na}$ show fly ash/slag ratios ranging from 1.5 to 6.3 while the usually low volatile elements display fly ash/slag ratios ranging from 0.4 to 2 , respectively.

The high enrichment of IGCC fly ash in the above elements may be attributed to the following major causes: (a) the high slag/fly ash ratio of the entrained flow gasifiers compared with pulverised coal combustion (90:10) accounts for the high content of condensing material (with a high proportion of partially volatilised elements) with respect to the non-volatile Al-Si glass. In absolute values the total amount of metals and semi-metals present in gasification and combustion by-products (slag and fly ash) is similar, or even lower in IGCC (vs. PCC) since a lower proportion of coal is used in the feed fuel; (b) the use of petroleum coke with high $\mathrm{V}$ and $\mathrm{Ni}$ contents in the IGCC and; (c) the relatively high contents of $\mathrm{Pb}, \mathrm{Sb}, \mathrm{Zn}$ and other trace elements in the Puertollano coal when compared with other world wide coals.

\subsection{Partitioning of major and trace elements}

The partitioning of trace elements allowed to the following classification for major and trace elements according to their volatile behaviour during co-gasification of coal and pet-coke in a entrained flow gasifier:

- High volatile elements (70-99\% in gas phase): $\mathrm{Hg}, \mathrm{Cl}$ and $\mathrm{S}$.

- Moderately volatile elements (up to $40 \%$ in gas phase and $\geqslant 60 \%$ in fly ash): As, Sb, B, F, Cd, Tl, Se, Zn and Sn.

- Elements with high condensation potential: (>90\% in fly ash): $\mathrm{Pb}, \mathrm{Ge}, \mathrm{Ga}$ and $\mathrm{Bi}$.

- Elements enriched similarly in fly ash and slag (30-60\% in fly ash): $\mathrm{Cu}, \mathrm{W},(\mathrm{P}), \mathrm{Mo}, \mathrm{Ni}$ and $\mathrm{Na}$. 
Table 4

Content of $C$, major oxides (\%) and trace elements (mg/kg, db) of the slag (S) and fly ash (FA) samples of the sample sets selected for this study.

\begin{tabular}{|c|c|c|c|c|c|c|c|c|}
\hline & S\#1 & $5 \# 2$ & S\#3 & $5 \# 4$ & FA\#1 & FA\#2 & FA\#3 & FA\#4 \\
\hline 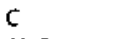 & 0.4 & 0.2 & 2.4 & 4.0 & 3.8 & 5.5 & 2.3 & 2.8 \\
\hline $\mathrm{Al}_{2} \mathrm{O}_{3}$ & 24.5 & 26.0 & 24.9 & 23.0 & 22 & 19 & 20 & 19 \\
\hline $\mathrm{CaO}$ & 7.5 & 5.4 & 4.9 & 7.0 & 3.1 & 3.5 & 3.5 & 3.2 \\
\hline $\mathrm{Fe}_{2} \mathrm{O}_{3}$ & 4.5 & 7.4 & 7.0 & 6.2 & 4.6 & 4.8 & 4.8 & 5.0 \\
\hline $\mathrm{K}_{2} \mathrm{O}$ & 1.9 & 2.2 & 2.2 & 2.1 & 3.7 & 3.8 & 4.0 & 4.1 \\
\hline MgO & 1.0 & 0.6 & 0.9 & 1.0 & 0.6 & 0.7 & 0.8 & 0.7 \\
\hline MnO & 0.1 & 0.1 & 0.1 & 0.1 & - & 0.03 & 0.01 & 0.04 \\
\hline $\mathrm{Na}_{2} \mathrm{O}$ & $<0.01$ & 0.3 & 0.3 & 0.3 & 0.5 & 0.5 & 0.2 & 0.6 \\
\hline$P_{2} O_{5}$ & 0.0 & $<0.01$ & 0.1 & 0.1 & 0.5 & 0.7 & - & 0.7 \\
\hline $\mathrm{SiO}_{2}$ & 59.2 & 51.8 & 50.5 & 50.2 & 57 & 52 & 54 & 56 \\
\hline $\mathrm{SO}_{3}$ & 1.0 & 2.4 & 2.1 & 1.7 & 2.8 & 3.5 & 3.0 & 3.3 \\
\hline $\mathrm{TiO}_{2}$ & 0.6 & 0.7 & 0.8 & 0.7 & 0.6 & 0.6 & 0.7 & 0.6 \\
\hline \multicolumn{9}{|l|}{$\mathrm{mg} / \mathrm{kg}$} \\
\hline $\mathrm{Cl}$ & 858 & 1372 & 653 & 500 & $<500$ & 823 & 353 & 500 \\
\hline B & 44 & 42 & 51 & 66 & $<500$ & 453 & 471 & 519 \\
\hline $\mathbf{F}$ & 43 & 54 & 62 & 548 & 2811 & 2845 & 3298 & 3816 \\
\hline $\mathrm{Br}$ & - & $<0.1$ & $<0.1$ & $<0.1$ & - & 40.8 & 24.5 & 28.5 \\
\hline 1 & - & $<0.1$ & $<02$ & 1.7 & & 70.6 & 472 & 53.0 \\
\hline As & 7.3 & 9.4 & 9.3 & 7.0 & 677 & 621 & 613 & 707 \\
\hline $\mathrm{Ba}$ & 607 & 647 & 645 & 574 & 386 & 424 & 440 & 421 \\
\hline $\mathrm{Be}$ & 10.9 & 9.2 & 8.1 & 7.3 & 14 & 10 & 10 & 9 \\
\hline $\mathrm{Bi}$ & 0.7 & $<0.01$ & 0.03 & 0.03 & 8 & 1 & 8.0 & 6.8 \\
\hline Cd & 0.4 & $<0.01$ & 0.3 & 0.2 & 17 & 17 & 22 & 20 \\
\hline Co & 23 & 40 & 34 & 27 & 56 & 43 & 39 & 40 \\
\hline $\mathrm{Cr}$ & 99 & 121 & 123 & 100 & 163 & 124 & 123 & 195 \\
\hline Cs & 61 & 51 & 52 & 47 & 185 & 127 & 149 & 133 \\
\hline Cu & 28 & 56 & 56 & 40 & 353 & 326 & 269 & 334 \\
\hline $\mathrm{Ga}$ & 0.9 & 3.0 & 3.0 & 2.4 & 247 & 262 & 306 & 264 \\
\hline $\mathrm{Ge}$ & 0.2 & 0.0 & 1.1 & 0.5 & 232 & 238 & 255 & 377 \\
\hline $\mathrm{Hf}$ & 7.3 & 7.4 & 21.6 & 18.2 & 8 & 6 & $\mathbf{5 . 6}$ & 4.3 \\
\hline $\mathrm{Hg}(\mu \mathrm{g} / \mathrm{kg})$ & 2.2 & 2.3 & 1.3 & 1.2 & 0.3 & 1.2 & 2.4 & 4.8 \\
\hline li & 156 & 196 & 143 & 171 & 156 & 186 & 171 & 233 \\
\hline Mo & 17 & 41 & 25 & 16 & 137 & 113 & 82 & 94 \\
\hline $\mathrm{Nb}$ & 20 & 21 & 20 & 18 & 28 & 25 & 19 & 15 \\
\hline $\mathrm{Ni}$ & 342 & 828 & 450 & 460 & 2153 & 1809 & 1031 & 1621 \\
\hline $\mathrm{Pb}$ & 6 & 6 & 5 & 8 & 3405 & 2855 & 3595 & 4063 \\
\hline$R \mathbf{b}$ & 103 & 108 & 132 & 102 & 282 & 209 & 264 & 208 \\
\hline Sb & 4.5 & $<0.01$ & 1.9 & 2.0 & 412 & 415 & 461 & 544 \\
\hline Sc & 21 & 18 & 95 & 77 & 114 & 13 & 85 & 67 \\
\hline Se & 8.0 & 0.3 & 0.4 & 0.3 & 4 & 6 & 11 & 7 \\
\hline Sn & 1.2 & 1.3 & 0.4 & 0.5 & 64 & 59 & 64 & 54 \\
\hline $\mathrm{Sr}$ & 124 & 133 & 154 & 135 & 99 & 114 & 120 & 118 \\
\hline $\mathrm{Ta}$ & 7.0 & 11 & 1.7 & 2.9 & 8 & 10 & 2 & 2 \\
\hline Th & 30 & 25 & 25 & 21 & 22 & 18 & 21 & 17 \\
\hline TI & $<0.01$ & 7.4 & 0.1 & 0.1 & 15 & 19 & 16 & 13 \\
\hline $\mathrm{U}$ & 15 & 25 & 8 & 8 & 15 & 20 & 11 & 9 \\
\hline v & 3444 & 2852 & 1681 & 2267 & 5591 & 5245 & 2813 & 4916 \\
\hline$W$ & 8 & 22 & 5 & 6 & 59 & 81 & 29 & 35 \\
\hline Y & 51 & 43 & 54 & 47 & 43 & 27 & 42 & 35 \\
\hline $\mathrm{Zn}$ & 13 & 13 & 25 & 22 & 5785 & 6242 & 6540 & 7788 \\
\hline $\mathrm{Zr}$ & 211 & 141 & 175 & 147 & 147 & 106 & 126 & 101 \\
\hline
\end{tabular}

- Low volatile elements ( $>70 \%$ in the slag): $\mathrm{Cs}, \mathrm{Rb}, \mathrm{Co}, \mathrm{K}, \mathrm{Cr}, \mathrm{V}, \mathrm{Nb}$, Be, Hf, Ta, Fe, U, Ti, Al, Si, Y, Sr, Th, Zr, Mg, Ba. Mn, REEs, Ca and Li.

The calculated EFs (Table 5) revealed that highly volatile elements are generally depleted in fly ash and slag with EF fly ash ranging from $<0.01$ to 1.5 and EF slag from $<0.01$ to 0.4 . The moderately volatile elements and the elements with high condensation potential show high EF fly ash (2.2-10.2 and 6.2-10.4, respectively) and are depleted in slag, with low EF slag (0.03-0.6 and 0.01-0.4, respectively). The elements enriched similarly in fly ash and slag show similar EFs in fly ash and slag but $P$ and Na may show enrichment in fly ash at low limestone dosages. The low volatile elements show $\mathrm{EF}_{\mathrm{FA}}$ close to 1 , but specific elements (such as $\mathrm{K}, \mathrm{V}, \mathrm{U}, \mathrm{Co}, \mathrm{Cr}$, $\mathrm{Fe}, \mathrm{Si}, \mathrm{Ti}, \mathrm{Rb})$ may be slightly enriched in fly ash $\left(\mathrm{EF}_{\mathrm{FA}}=1.3-2.3\right)$ at low limestone dosages ( $\mathrm{K}, \mathrm{Co}, \mathrm{Fe}, \mathrm{Si}, \mathrm{Cr}, \mathrm{Ti}, \mathrm{Mo}$ and $\mathrm{Rb}$ ) and high pet-coke addition ( $V$ and $U$ ).

\subsubsection{High volatile elements}

This group includes the high volatile $\mathrm{Hg}, \mathrm{Br}, \mathrm{I}, \mathrm{Cl}$ and $\mathrm{S}$. These elements partially volatilise during gasification and remain in high proportions in the gas phase at fly ash removal temperatures $\left(265^{\circ} \mathrm{C}\right.$ ), pointing out the occurrence of species with low boiling points. Thus, $\mathrm{Hg}$ most probably occurs as high volatile [11] $\mathrm{Hg}^{0}$, which accounts for the high proportions (>99\%) of this metal in gas phase at fly ash removal temperatures (Fig. 2). The low proportions of $\mathrm{Hg}$ retained in fly ahs may be related to the occurrence of $\mathrm{Hg}_{2} \mathrm{Cl}_{2}$. The high positive correlation among $\mathrm{Ca}$ and $\mathrm{Hg}\left(R^{2}=0.96\right.$, with the exception of set \#4) and low negative correlation between $\mathrm{C}$ and $\mathrm{Hg}\left(\mathrm{R}^{2}=0.33\right)$ contents in fly ash suggest that $\mathrm{Hg}_{2} \mathrm{Cl}_{2}$ is adsorbed by $\mathrm{CaO}$ rather than for char particles as reported by other authors [36]. The high volatile character of $\mathrm{Br}$ and $\mathrm{I}$ bearing species [37], most of them having boiling points $<184^{\circ} \mathrm{C}$, account for their high proportions in gas phase ( $>98 \%$ and $85-89 \%$, respectively, Fig. 2) at fly ash removal temperatures, despite the major associa- 
Table 5

Enrichment factors for slag (EF slag) and fly ash (EFfly ash) and mass balances (MB) for the sample sets investigated.

\begin{tabular}{|c|c|c|c|c|c|c|c|c|c|c|c|c|}
\hline & \multicolumn{4}{|c|}{ Fly ash/slag ratio } & \multicolumn{4}{|l|}{ EF slag } & \multicolumn{4}{|c|}{ EF fly ash } \\
\hline & $\# 1$ & $\# 2$ & \#3 & $\# 4$ & $\# 1$ & $\# 2$ & $\# 3$ & $\# 4$ & \#1 & $\# 2$ & \#3 & $\# 4$ \\
\hline Al & 0.9 & 0.7 & 0.8 & 0.8 & 1.0 & 1.0 & 1.0 & 1.0 & 1.0 & 1.0 & 1.0 & 1.0 \\
\hline $\mathrm{Ca}$ & 0.4 & 0.6 & 0.7 & 0.5 & 1.0 & 1.0 & 1.1 & 1.0 & 0.6 & 0.6 & 0.6 & 0.6 \\
\hline $\mathrm{Fe}$ & 1.0 & 0.6 & 0.7 & 0.8 & 0.9 & 1.0 & 1.0 & 1.0 & 1.4 & 0.9 & 0.9 & 1.0 \\
\hline K & 1.9 & 1.7 & 1.8 & 2.0 & 0.9 & 0.9 & 0.8 & 0.9 & 2.3 & 2.3 & 2.0 & 2.0 \\
\hline $\mathrm{Mg}$ & 0.6 & 1.2 & 0.9 & 0.7 & 0.9 & 1.0 & 1.0 & 1.0 & 1.2 & 0.8 & 0.8 & 0.9 \\
\hline Mn & - & 0.3 & 0.1 & 0.4 & 0.9 & 1.0 & 1.0 & 1.0 & 1.4 & 0.8 & 0.7 & 0.9 \\
\hline $\mathrm{Na}$ & $>50$ & 1.7 & 0.7 & 2.0 & 0.8 & 0.2 & 0.9 & 0.9 & 2.6 & 1.1 & 1.8 & 1.8 \\
\hline$P$ & - & - & - & 7.0 & 0.2 & 0.9 & 0 & 0.4 & 8.1 & 2.1 & 10.1 & 6.1 \\
\hline $5 i$ & 1.0 & 1.0 & 1.1 & 1.1 & 1.1 & 0.9 & 1.0 & 1.0 & 1.0 & 1.0 & 1.3 & 1.3 \\
\hline 5 & 2.8 & 1.5 & 1.4 & 1.9 & 0.03 & 0.1 & 0.3 & 0.1 & 0.1 & 0.3 & 0.4 & 0.1 \\
\hline $\mathrm{Ti}$ & 1.0 & 0.9 & 0.9 & 0.9 & 1.0 & 1.0 & 1.0 & 1.0 & 1.3 & 1.2 & 1.0 & 1.0 \\
\hline $\mathrm{Cl}$ & 0.6 & 0.6 & 0.5 & 1.0 & 0.1 & 0.2 & 0.1 & 0.1 & 0.1 & 02 & 0.1 & 0.1 \\
\hline B & $>11$ & 11 & 9.2 & 7.9 & 0.4 & 0.3 & 0.4 & 0.4 & 4.9 & 4.9 & 4.5 & 4.0 \\
\hline $\mathbf{F}$ & 65 & 53 & 53 & 7 & 0.1 & 0.1 & 0.1 & & 6.7 & 6.5 & 7.3 & - \\
\hline $\mathrm{Br}$ & - & 408 & 245 & 285 & - & $<0.01$ & $<0.01$ & $<0.01$ & - & 1.4 & 1.5 & 1.5 \\
\hline 1 & - & 706 & 236 & 31 & - & $<0.01$ & $<0.01$ & $<0.01$ & - & 0.2 & 0.2 & 0.2 \\
\hline As & 93 & 66 & 66 & 101 & 0.1 & 0.1 & 0.1 & 0.1 & 5.9 & 5.3 & 7.6 & 9.4 \\
\hline $\mathrm{Ba}$ & 0.6 & 0.7 & 0.7 & 0.7 & 1.1 & 1.0 & 1.1 & 1.0 & 1.0 & 0.8 & 0.9 & 0.9 \\
\hline $\mathrm{Be}$ & 1.3 & 1.1 & 1.2 & 1.2 & 0.9 & 0.9 & 1.0 & 1.0 & 1.0 & 1.0 & 1.4 & 1.4 \\
\hline $\mathrm{Bi}$ & 11 & 100 & 267 & 227 & 0.4 & 0.01 & 0.01 & 0.01 & 6.2 & 10.4 & 9.7 & 9.6 \\
\hline Cd & 43 & 1700 & 73 & 100 & 0.2 & $<0.01$ & 0.1 & 0.1 & 7.1 & 9.4 & 8.4 & 7.4 \\
\hline $\mathrm{Co}$ & 2.4 & 1.1 & 1.1 & 1.5 & 0.9 & 0.9 & 1.0 & 0.9 & 1.7 & 1.3 & 1.3 & 1.6 \\
\hline $\mathrm{Cr}$ & 1.6 & 1.0 & 1.0 & 2.0 & 0.9 & 0.9 & 1.0 & 0.9 & 1.6 & 1.2 & 1.2 & 2.1 \\
\hline Cs & 3.0 & 2.5 & 2.9 & 2.8 & 0.7 & 0.8 & 0.8 & 0.8 & 2.9 & 2.5 & 2.7 & 2.7 \\
\hline $\mathrm{Cu}$ & 13 & 5.8 & 4.8 & 8.4 & 0.4 & 0.6 & 0.7 & 0.5 & 5.8 & 4.3 & 3.9 & 5.0 \\
\hline $\mathrm{Ga}$ & 274 & 87 & 102 & 110 & 0.04 & 0.1 & 0.1 & 0.1 & 9.8 & 8.9 & 9.3 & 8.9 \\
\hline $\mathrm{Ge}$ & 1160 & - & 232 & 754 & 0.01 & $<0.01$ & 0.04 & 0.01 & 9.6 & 9.9 & 9.7 & 9.9 \\
\hline $\mathrm{HF}$ & 1.1 & 0.8 & 0.3 & 0.2 & 1.0 & 1.0 & 1.0 & 1.0 & 1.1 & 1.1 & 0.9 & 0.9 \\
\hline $\mathrm{Hg}$ & 0.1 & 0.5 & 1.8 & 4.0 & 0.003 & 0.001 & 0.002 & 0.001 & 0.001 & 0.002 & 0.003 & 0.006 \\
\hline Li & 1.0 & 0.9 & 1.2 & 1.4 & 1.0 & 1.0 & 0.9 & 0.9 & 1.6 & 1.2 & 1.3 & 1.5 \\
\hline Mo & 8.1 & 2.8 & 3.3 & 5.9 & 0.5 & 0.7 & 0.8 & 0.7 & 5.2 & 2.7 & 3.2 & 4.5 \\
\hline Nd & 1.4 & 1.2 & 1.0 & 0.8 & 1.0 & 1.0 & 1.0 & 1.0 & 0.8 & 0.8 & 0.9 & 0.8 \\
\hline $\mathrm{Ni}$ & 6.3 & 2.2 & 2.3 & 3.5 & 0.7 & 0.8 & 0.8 & 0.7 & 4.6 & 2.4 & 2.2 & 3.1 \\
\hline $\mathrm{Pb}$ & 568 & 476 & 719 & 508 & 0.01 & 0.02 & 0.01 & 0.02 & 9.1 & 9.9 & 9.9 & 9.4 \\
\hline $\mathrm{Rb}$ & 2.7 & 1.9 & 2.0 & 2.0 & 0.8 & 0.9 & 0.9 & 0.9 & 2.4 & 2.3 & 2.1 & 2.1 \\
\hline $5 b$ & 92 & - & 243 & 272 & 0.1 & $<0.01$ & 0.03 & 0.03 & 5.4 & 5.7 & 9.0 & 10.2 \\
\hline $5 c$ & 5.4 & 0.7 & 0.9 & 0.9 & 1.1 & 1.0 & 1.0 & 1.0 & 0.8 & 1.0 & 1.0 & 1.1 \\
\hline Se & 0.5 & 20 & 28 & 23 & - & 0.1 & 0.2 & 0.1 & - & 6.9 & 8.9 & 8.6 \\
\hline $\mathrm{Sn}_{n}$ & 53 & 45 & 160 & 108 & 0.2 & 0.1 & 0 & 0.1 & 8.6 & 5.9 & 9.2 & 8.5 \\
\hline Sr & 0.8 & 0.9 & 0.8 & 0.9 & 1.0 & 1.0 & 1.0 & 1.0 & 1.1 & 1.1 & 0.9 & 1.0 \\
\hline $\mathrm{Ta}$ & 1.1 & 0.9 & 1.2 & 0.7 & 1.1 & 0.9 & 1.0 & 1.0 & 0.5 & 1.1 & 1.1 & 1.0 \\
\hline Th & 0.7 & 0.7 & 0.8 & 0.8 & 1.0 & 1.0 & 1.0 & 1.0 & 0.9 & 0.9 & 1.0 & 1.0 \\
\hline $\mathrm{Tl}$ & 1500 & 2.6 & 160 & 130 & $<0.01$ & 0.6 & 0.05 & 0.04 & 7.5 & 2.2 & 9.1 & 7.8 \\
\hline $\mathrm{U}$ & 1.0 & 0.8 & 1.4 & 1.1 & 1.0 & 1.1 & 1.0 & 1.0 & 1.2 & 1.1 & 1.5 & 1.4 \\
\hline V & 1.6 & 1.8 & 1.7 & 2.2 & 0.9 & 0.8 & 0.9 & 0.9 & 1.7 & 2.0 & 1.9 & 22 \\
\hline$W$ & 7.4 & 3.7 & 5.8 & 5.8 & 0.5 & 0.7 & 0.6 & 0.6 & 5.7 & 3.5 & 4.4 & 42 \\
\hline $\mathrm{Y}$ & 0.8 & 0.6 & 0.8 & 0.7 & 1.0 & 1.1 & 1.0 & 1.0 & 1.0 & 0.9 & 0.9 & 0.9 \\
\hline $\mathrm{Zn}$ & 445 & 480 & 262 & 354 & 0.02 & 0.01 & 0.02 & 0.02 & 9.9 & 6.2 & 7.3 & 9.9 \\
\hline $\mathrm{Zr}$ & 0.7 & 0.8 & 0.7 & 0.7 & 1.0 & 1.0 & 1.0 & 1.1 & 1.0 & 1.0 & 0.9 & 0.9 \\
\hline
\end{tabular}

tion with the coal ash components than with the organic matter of coal (Tables 2 and 3).The proportion of $\mathrm{Br}$ and I retained in fly ash may be related to unburned pet-coke particles containing $\mathrm{Br}$ and $\mathrm{I}$ as suggested by the simultaneous increase of these elements and unburned $C$ in fly ash (Table 4). The association of Br organicallybound in coal, with char particles in fly ash was also suggested in studies on the behaviour of this element during coal combustion [38]. Nevertheless, the occurrence of less volatile Br bearing species, such as $\mathrm{NaBr}$, cannot be rule out.

The proportion of $\mathrm{Cl}$ and $\mathrm{S}$ in gas phase ranges from 88 to $>99 \%$ and 68 to $96 \%$, respectively (Fig. 2). The remaining $\mathrm{Cl}$ and $\mathrm{S}$ are distributed in slag rather than in fly ash (Fig. 2). Since the volatile fraction of $\mathrm{Cl}$ correlates negatively with the $\mathrm{Cl}$ content in the feed coal $\left(R^{2}=0.79\right)$, the high volatility of $\mathrm{Cl}$ is probably due to the high content of organic $\mathrm{Cl}$ arising from pet-coke. In the feed coal, $\mathrm{Cl}$ most probably occurs in refractory phosphate minerals, such as apatite, rather than to organic matter, as suggested by the high correlation of $\mathrm{Cl}$ with $\mathrm{U}\left(R^{2}=0.93\right)$, Be $(0.82)$ and $\mathrm{Li}(0.64)$, elements with phos- phate and Al-Si affinity in the Puertollano coal [23]. The occurrence of these low volatile $\mathrm{Cl}$ species may partially account for the considerable proportions of $\mathrm{Cl}$ retained in the slag. The positive trend between $\mathrm{Cl}$ and $\mathrm{Al}\left(\mathrm{R}^{2}=0.76\right), \mathrm{U}(0.98)$ and REE's $(0.80)$ in the slag samples suggest that most of the $\mathrm{Cl}$ bound to refractory minerals of coal, may be dissolved and retained in the Al-Si melt (process controlled by diffusion in the melt) or retained as fluid inclusions, as reported for coal combustion [38]. In this regard, the level of limestone dosage seems to be the most important feed parameter affecting $\mathrm{Cl}$ and $\mathrm{S}$ volatility, as suggested by the negative correlation between the limestone content in the feed fuel blend and the $\mathrm{Cl}$ and $\mathrm{S}$ volatile fractions $\left(R^{2}=0.91\right.$ and 0.38 , respectively). High limestone content reduces the volatile fraction of $\mathrm{Cl}$ and $\mathrm{S}$ while increases their enrichment in slag. For $\mathrm{Cl}$, high $\mathrm{Ca}$ contents may favour the above mentioned dissolution in the A-Si melt. In summary, both, the high $R^{2}$ correlation factors of $\mathrm{Cl}$ content with $\mathrm{Al}, \mathrm{U}$ and REEs in the slag, which in turn are associated with $\mathrm{Zr}$, supports that the partial occurrence of $\mathrm{Cl}$ in refractory minerals 

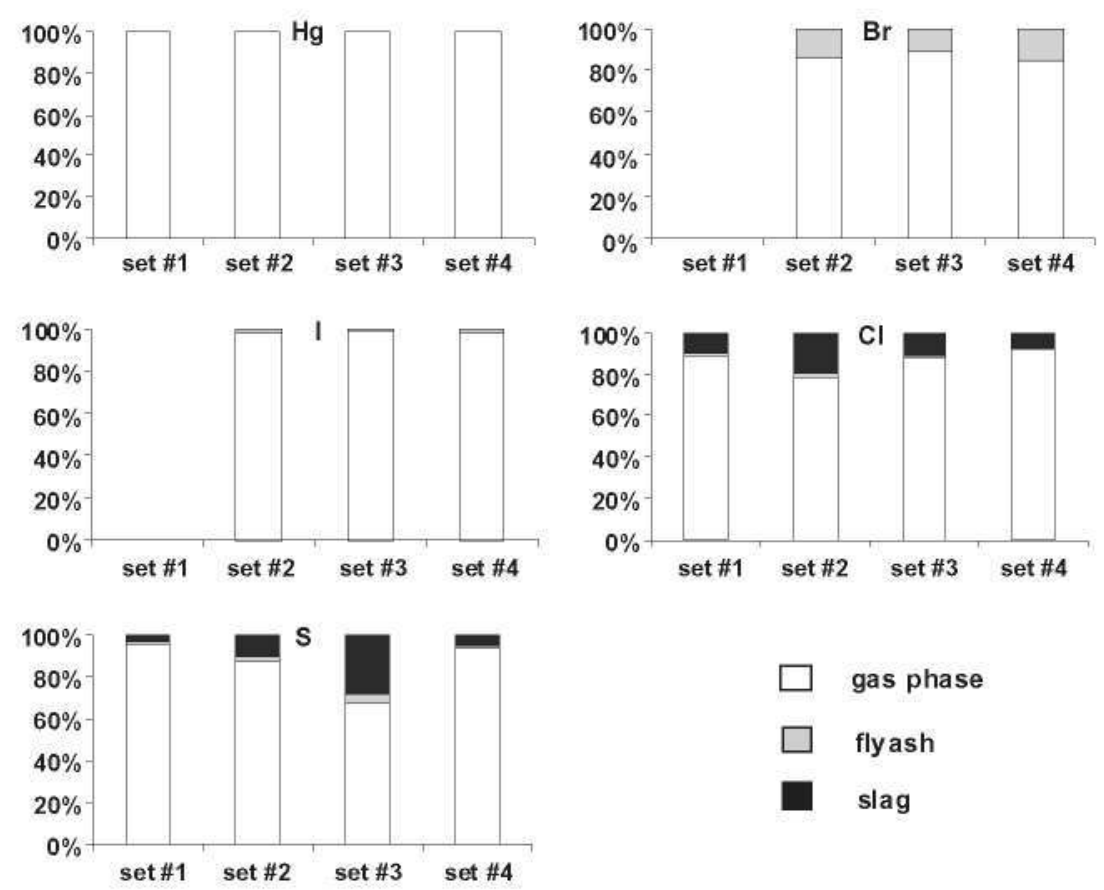

Fig. 2. Normalised mass balance for high volatile elements ( $>70 \%$ in gas phase).

in the Puertollano coal and the trapping of $\mathrm{Cl}$ in melt, especially at high $\mathrm{Ca}$ dosages are the most important causes for retaining $\mathrm{Cl}$ in the slag reducing its volatile fraction. For $\mathrm{S}$, the enrichment in slag rather than in fly ash is attributed to the formation of pyrrhotitemillerite $\left(\mathrm{Fe}_{1-x} \mathrm{~S}-\mathrm{NiS}\right)$ when increasing limestone content. The occurrence of these sulphide species in the slag is deduced from the high correlation $\left(R^{2}=0.6-0.8\right)$ between limestone content and those of sulphide bearing elements ( $\mathrm{S}, \mathrm{Fe}, \mathrm{Ni}, \mathrm{Mo}, \mathrm{Cu}$ and $\mathrm{Co}$ ).

\subsubsection{Moderately volatile elements (up to $40 \%$ in gas phase and $\geqslant 60 \%$ in fly ash)}

This group of elements includes As, Sb, Se, B, F, Cd, Tl, Se, Zn and $\mathrm{Sn}$. High proportions of these elements volatilise during gasification [11], and partially condense during the flue gas cooling. However, a significant proportion of those may remain in gas phase at fly ash removal temperatures. Within this group the following subgroups can be differentiate as a function of the proportion in gas phase (Fig. 3):

- $50-90 \%$ in fly ash and up to $43 \%$ in gas phase: includes As $(<0.01-42 \%$ in gas phase), Sb $(<0.01-43 \%), \mathrm{Zn}(0-37 \%)$ and $\mathrm{Sn}$ $(<0.01-32 \%)$.

- >65\% in fly ash up to $25 \%$ in gas phase: $\mathrm{Cd}(6-20 \%), \mathrm{Tl}(5-32 \%)$ and Se (0-23\%).

- Up to $21 \%$ in gas phase: $\mathrm{B}(17-20 \%)$ and $\mathrm{F}(18-21 \%)$.

The levels of volatile $\mathrm{Cl}$ and the limestone content of the feed fuel blend account for the variability of the proportions of As, Sb, $\mathrm{Zn}, \mathrm{Sn}, \mathrm{Cd}, \mathrm{Tl}$ and $\mathrm{Se}$ as gaseous species. Thus, the proportions of $\mathrm{As}, \mathrm{Sb}, \mathrm{Tl}$ and $\mathrm{Se}$ in gas phase at fly ash removal temperatures increased as $\mathrm{Cl}$ content in pet-coke increases An increased content of gaseous $\mathrm{Cl}$ may favours a high occurrence of high volatile As, $\mathrm{Tl}, \mathrm{Sb}$ and $\mathrm{Se}$ chloride species, such as $\mathrm{AsCl}_{3}$ (boiling point $\left.130^{\circ} \mathrm{C}\right), \mathrm{SbCl}_{3}\left(220^{\circ} \mathrm{C}\right), \mathrm{SnCl}_{5}\left(140^{\circ} \mathrm{C}\right), \mathrm{TlCl}_{3}\left(155^{\circ} \mathrm{C}\right)$ and $\mathrm{Se}_{2} \mathrm{Cl}_{2}$ $\left(127^{\circ} \mathrm{C}\right.$ ) [37]. Conversely, the volatile proportions of $\mathrm{Zn}, \mathrm{Sn}$ and $\mathrm{Cd}$ are reduced when the limestone content in the feed fuel blend increases. As previously stated, low proportions of $\mathrm{Cl}$ levels in the gas phase are caused by high limestone dosages. Under these conditions the condensation of $\mathrm{Zn}, \mathrm{Sn}$ and $\mathrm{Cd}$ sulphides is favoured rather than the formation of gaseous chloride species [11], such as $\mathrm{ZnCl}_{2}$. Furthermore, the proportion of $\mathrm{As}$ and $\mathrm{Sb}$ in gas phase could be also controlled by the levels of $\mathrm{Ni}$ in the feed fuel [39], available to form nickeline-brethautite in this gasification fly ash. The high organic affinity of B ( $60 \%$ of the bulk B) in the feed coal $[14,15]$ and, in pet-coke (close to $100 \%$ ) accounts for the high volatility of this element in IGCC. As reported by several authors $[14,15,40]$ the mode of occurrence of $B$ in coal is controlling its volatile behaviour during combustion. The occurrence of B in tourmalines or other silicate minerals reduce the volatility, whereas a mainly organic affinity favours the occurrence of B in the gas phase. In a similar way the mode of occurrence of $F$ in the feed fuel controls the release of this element to the gas phase. In the feed coal of Puertollano IGCC plant, $\mathrm{P}\left(R^{2}=0.81\right)$ and $\mathrm{Al}-\mathrm{Si}$ affinity is deduced for $\mathrm{F}$, suggesting a major occurrence in apatite or in silicates. Therefore, the F organically-bound in pet-coke should be the major source for volatile $\mathrm{F}$.

Although a highly volatile proportion of B and F is available, only small proportions of these elements (up to $21 \%$ and $25 \%$, respectively) remain in the gas phase at fly ash removal temperatures (Fig. 3). B is retained in fly ash $(40-49 \%)$ rather than in slag (31-38\%, Fig. 3). Probably volatile B occurs as oxide species $\left(\mathrm{B}_{2} \mathrm{O}_{3}\right),[11]$ which is retained in fly ash by the condensation and/ or adsorption on the Al-rich fly ash particles as suggested by other authors $[33,40]$ and supported by the correlation between $\mathrm{B}$ and $\mathrm{Al}$ contents $\left(R^{2}=0.60\right)$ in Puertollano IGCC fly ash. The main causes for retaining $B$ in the slag are probably the low volatility of B bearing silicates in coal, which may give rise to retain $\mathrm{B}$ in the $\mathrm{Al}-\mathrm{Si}$ glass matrix of the slag, and the high affinity of $\mathrm{B}$ to $\mathrm{Ca}$ to form Ca borates, such as takaidite $\left(\mathrm{Ca}_{3} \mathrm{~B}_{2} \mathrm{O}_{6}\right)$, especially in reducing environments [39].

$\mathrm{F}$ is mainly occurring in fly ash (65-73\%) and only a small proportion $(7-10 \%)$ is retained in the slag. This partitioning may be the result of partial condensation of volatilised $\mathrm{F}$ during gas cooling. The relatively high correlations factors among contents of $\mathrm{F}$ and 


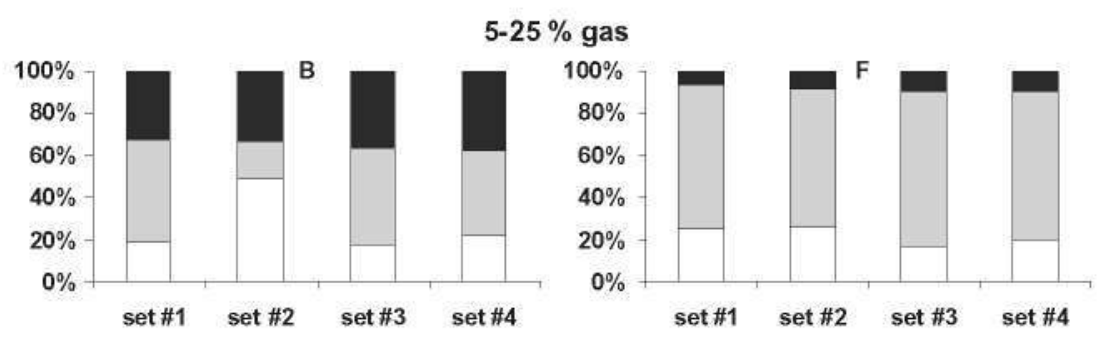

$50-90 \%$ fly ash, up to $40 \%$ gas
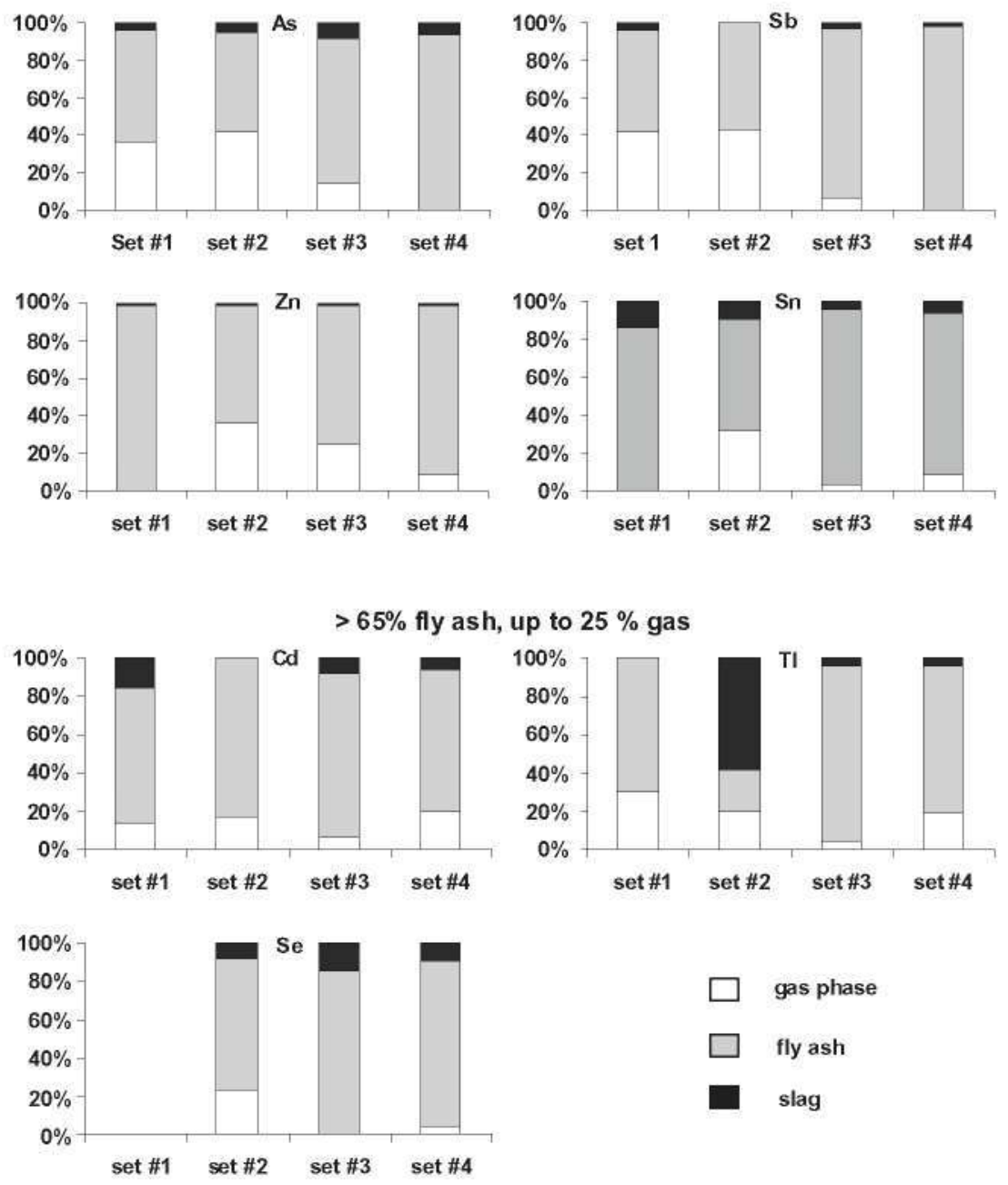

$$
\begin{aligned}
& \text { gas phase } \\
& \text { fly ash } \\
& \text { slag }
\end{aligned}
$$

Fig. 3. Normalised mass balance for relatively high volatile (up to $40 \%$ in gas phase).

$\mathrm{K}, \mathrm{Sr}$ and $\mathrm{Na}$ in fly ash suggest the formation of $\mathrm{K}-\mathrm{Na}-\mathrm{Sr}$ fluoride species during gasification as the main cause for the high retention of this element in fly ash.

\subsubsection{Elements with high condensation potential: ( $\geqslant 90 \%$ in fly ash):}

$\mathrm{Pb}, \mathrm{Ge}, \mathrm{Ga}$ and $\mathrm{Bi}$

This group includes elements that are partially volatilised during gasification and subsequently condense during gas cooling to form sulphide and oxide species. The complete volatilisation of these elements is caused by the high organic occurrence of $\mathrm{Ge}$ and the major sulphide affinity of $\mathrm{Pb}, \mathrm{Ga}$ and $\mathrm{Bi}$ in the Puertollano coal [23]. The high chalcophile affinity of these elements in reducing conditions account for the formation of sulphide species, such as galena for $\mathrm{PbS}, \mathrm{GeS}$ and $\mathrm{GeS}_{2}$ for Ge or substituting for $\mathrm{Zn}$ in sphalerite/wurtzite lattices for $\mathrm{Ga}$, and the consequent high retention of these elements in fly ash (Fig. 4).
Elements enriched similarly in fly ash and slag (30-60\% in fly ash): $\mathrm{Cu}, \mathrm{W},(\mathrm{P}), \mathrm{Mo}, \mathrm{Ni}$ and $\mathrm{Na}$. This group of elements includes $\mathrm{Cu}, \mathrm{W}, \mathrm{Mo}, \mathrm{Ni}$ and $\mathrm{Na}$, with proportions retained in fly ash ranging from $40-60 \%, 40-60 \%, 30-50 \%, 20-50 \%$ and $20-40 \%$, respectively (Fig. 5). Phosphorus is included in this group although the partitioning between slag and fly ash vary from $20 \%$ to $100 \%$ (Fig. 5). The limestone addition controls the enrichment of these metals and semi-metals in slag and fly ash, being enriched in slag rather than in fly ash for the highest limestone dosages, with correlation factors between limestone and the EF fly ash ranging from 0.70 to 0.99 .

\subsubsection{Low volatile elements ( $\geqslant 70 \%$ in the slag)}

This group of elements includes $\mathrm{Cs}, \mathrm{Rb}, \mathrm{Co}, \mathrm{K}, \mathrm{Cr}, \mathrm{V}, \mathrm{Nb}, \mathrm{Be}, \mathrm{Hf}$, $\mathrm{Ta}, \mathrm{Fe}, \mathrm{U}, \mathrm{Ti}, \mathrm{Al}, \mathrm{Si}, \mathrm{Y}, \mathrm{Sr}, \mathrm{Th}, \mathrm{Zr}, \mathrm{Mg}$, Ba. Mn, REEs, Ca and Li, being highly $(>70 \%)$ concentrated in the slag. The high retention of these 


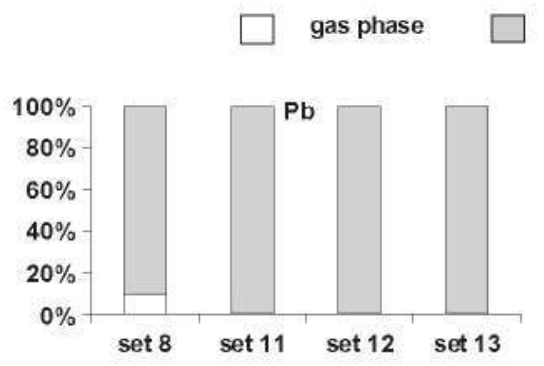

fly ash $\quad$ slag
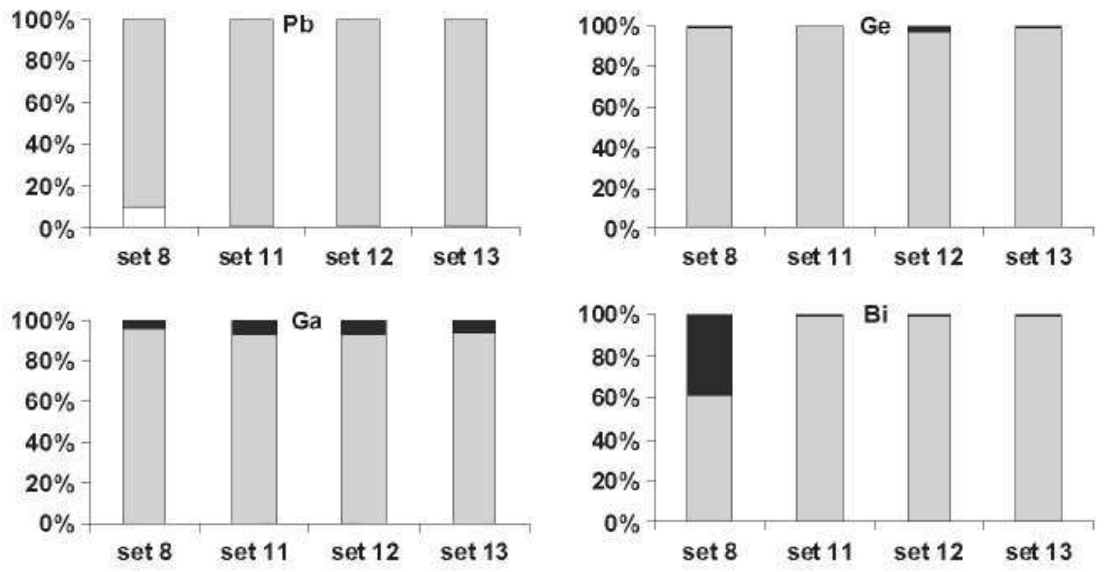

Fig. 4. Normalised mass balance for elements with high condensation potential.
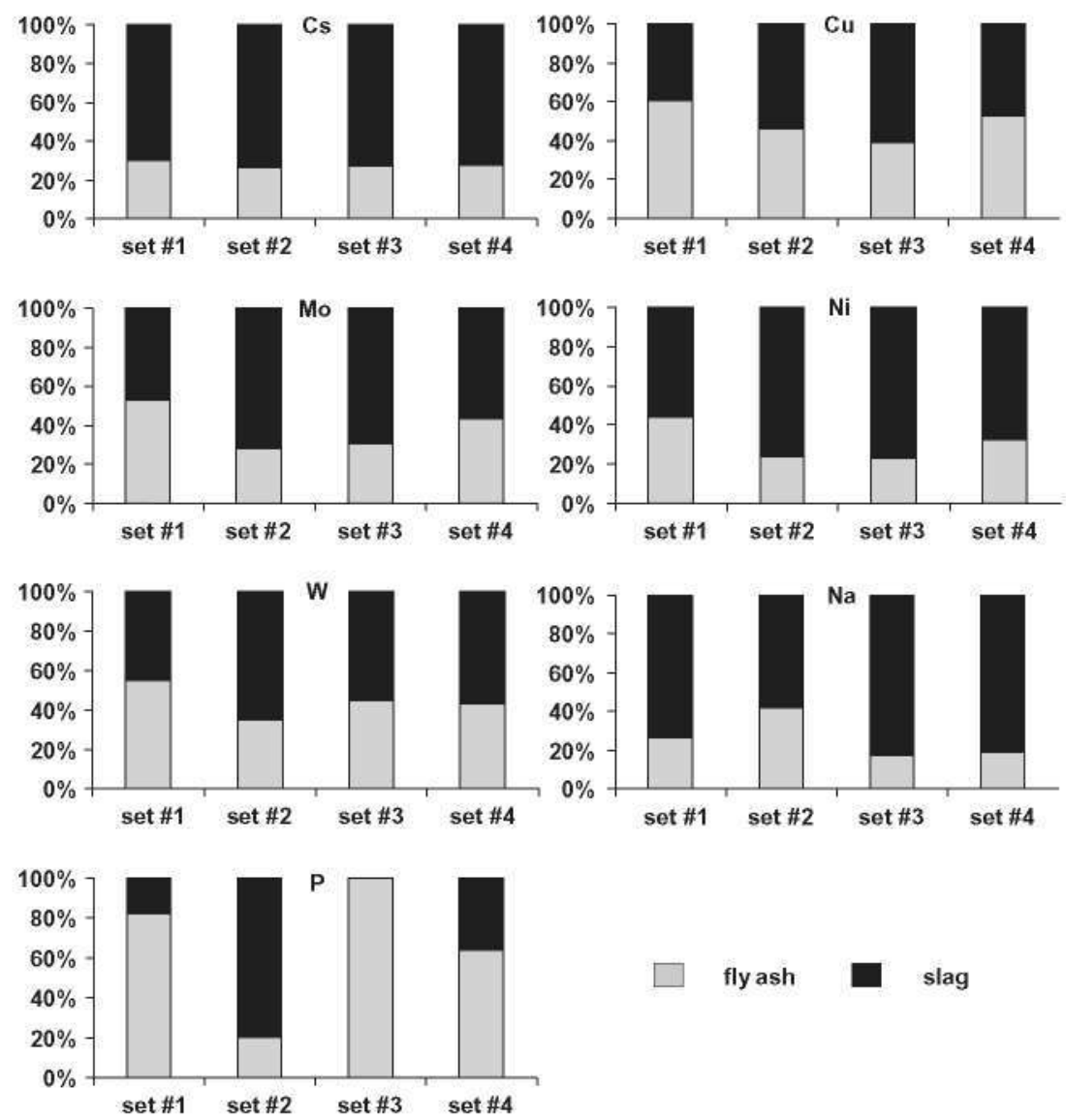

Fig. 5. Normalised mass balance for elements enriched similarly in fly ash and slag (30-60\% in fly ash).

elements in the slag is due to the high slagging conditions of the Puertollano plant favoured by the addition of limestone as a fluxing agent in the feed fuel blend.

With a number of exceptions (especially B, F and Se) the above partitioning of elements in entrained flow gasifiers according to their volatile behaviour during gasification is comparable with that reported for coal combustion plants $[14,15]$. The comparison of the partitioning obtained for the Puertollano IGCC power plant and that of a Spanish PCC power plant co-firing coal and pet-coke
[41] show a similar partitioning for the high volatile elements $\mathrm{Hg}, \mathrm{S}$, and $\mathrm{Cl}(70-100 \%$ in gas phase), but markedly differences on the partitioning of $\mathrm{F}, \mathrm{Se}, \mathrm{Sn}, \mathrm{B}, \mathrm{Cd}, \mathrm{Sb}, \mathrm{As}$ and $\mathrm{Zn}$. The volatile fraction of F, Se, and B is lower for IGCC than for co-combustion, whereas that of As, Sb, Cd and $\mathrm{Zn}$ is higher for IGCC than for PCC. The high volatility of $\mathrm{As}, \mathrm{Sn}, \mathrm{Cd}$ and $\mathrm{Zn}$ in IGCC is probably caused by the high $\mathrm{Cl}$ content of the feed fuel blend of the Puertollano IGCC plant (generally $1300-1700 \mathrm{mg} / \mathrm{kg}$ ) when compared with the feed fuel of the PCC plant (over $500 \mathrm{mg} / \mathrm{kg}$ ) and the high fly 
ash removal temperatures (265 and $150^{\circ} \mathrm{C}$ for IGCC and PCC plant, respectively). If the results of the PCC plant with that of set $\# \mathbf{4}$ from JGCC, with similar $\mathrm{Cl}$ content in the feed fuel, are compared, the volatile fraction of $\mathrm{F}, \mathrm{Se}, \mathrm{Sn}$ and $\mathrm{B}$ is lower than that of $\mathrm{PCC}$ even the IGCC fly ash removal temperatures. For this IGCC sample set, the volatile fraction of $\mathrm{As}$ and $\mathrm{Sb}$ reach the lowest values $(<1 \%$ volatile), similar to that obtained for $\mathrm{PCC}$. The volatile fractions of $\mathrm{Cd}$ and $\mathrm{Zn}$ ( $20 \%$ and $10 \%$, respectively) are lower than for other set but still slightly higher than obtained for $\mathrm{PCC}(5 \%$ and $<1 \%$, respectively). Therefore, the volatility of $\mathrm{As}$ and $\mathrm{Sb}$ and in minor degree that of $\mathrm{Cd}$ and $\mathrm{Zn}$ are controlled by the $\mathrm{Cl}$ content of the feed fuel for both, IGCC and PCC plants; reaching very similar partitioning between both power generation technologies. The low volatile proportion of F, Se, Sn and B in IGCC are related to the use of limestone as a fluxing agent in the Puertollano plant, which favours the retention of these elements in fly ash. The high slagging conditions of the Puertollano IGCC facility, account for the opposite distribution of low volatile elements between $\mathrm{IGCC}(>75 \%$ in slag) and $\mathrm{PCC}$ $(>75 \%$ in fly ash) according to the slag/fly ash ratio production.

\section{Conclusions}

The Partitioning in the Puertollano IGCC plant may be summarised as follows: (a) high volatile elements (70-99\% in gas phase): $\mathrm{Hg}, \mathrm{Cl}$ and S, (b) moderately volatile elements (up to $40 \%$ in gas phase and $\geqslant 60 \%$ in fly ash): As, Sb, B, F, Cd, Tl, Se, $\mathrm{Zn}$ and Sn, (c) elements with high condensation potential: (>90\% in fly ash): $\mathrm{Pb}$, $\mathrm{Ge}, \mathrm{Ga}$ and $\mathrm{Bi}$, (d) elements enriched similarly in fly ash and slag (30-60\% in fly ash): $\mathrm{Cu}, \mathrm{W},(\mathrm{P}), \mathrm{Mo}, \mathrm{Ni}$ and $\mathrm{Na}$ and (e) low volatile elements (>70\% in the slag): $\mathrm{Cs}, \mathrm{Rb}, \mathrm{Co}, \mathrm{S}, \mathrm{K}, \mathrm{Cr}, \mathrm{V}, \mathrm{Nb}, \mathrm{Be}, \mathrm{Hf}, \mathrm{Ta}, \mathrm{Fe}$, U, Ti, Al, Si, Y, Sr, Th, Zr, Mg, Ba, Mn, REEs, Ca and Li. The variability in the volatile behaviour of most of elements in IGCC is controlled by the addition of pet-coke and limestone to the feed fuel blend. Due to the high organic affinity of elements in pet-coke and the high $\mathrm{S}$ and $\mathrm{Cl}$ content supplied by this fuel, the addition of pet-coke increase the volatile behaviour and the proportion of As, Sb and Tl in the gas phase at removal fly ash temperatures, probably due to a high occurrence of high volatile As-Sn-Tl chloride species. The addition of limestone to the blend in the Puertollano IGCC plant, may change the viscosity of the melt, trapping chlorides and Sbearing species reducing the proportion in gas phase of $S$, and $\mathrm{Cl}$. Furthermore, the occurrence of $B$ in glass being trapped by the melt at high limestone dosages and in minor degree the potential occurrence of low volatile $\mathrm{Ca}$ borates accounts reducing volatility of $\mathrm{B}$.

The main differences among IGCC and PCC plants co-firing coal and pet-coke include: (a) a lower volatility of F, Se and Tl for lGCC plant than PCC due to the high occurrence of condensation processes during IGCC gas cooling and (b) the higher volatility of As, Sb, Sn, Zn and Cd for IGCC than for PCC due to the higher pet-coke proportion used in the gasification blend than in PCC. Furthermore, the slightly higher volatility of $\mathrm{Hg}$ in IGCC may be attributable to the relatively low unburned coal particles (char particles may adsorb $\mathrm{Hg}$ ) of the IGCC raw gas.

\section{Acknowledgements}

We wish to thank to European Commission-DG Research, Research Fund for Coal and Steel for supporting this study (RFC-CR04005 ). This work was carried out with a grant from the Research Fund for Coal and Steel of the European Community. The authors from the Universidad Politécnica de Madrid (UPM) thank the UPM support of Tar industrial research group. Also, the authors wish to thank to the reviewers for their useful suggestions for improving quality of the article.

\section{References}

[1] Bunt JR, Waanders FB. An understanding of the behaviour of a number of element phases impacting on a commercial-scale Sasol-lurgi FBDB gasifier. Fuel 2008;87:1751-62.

[2] Bunt JR, Waanders FB. Trace element behaviour in the Sasol-lurgi MK IV FBDB gasifier, Part 1 - the volatile elements: $\mathrm{Hg}, \mathrm{As}, \mathrm{Se}, \mathrm{Cd}$ and $\mathrm{Pb}$. Fuel 2008;87:2374-87.

[3| Bunt JR, Waanders FB. Trace element behaviour in the Sasol-lurgi MK IV FBDB gasifier. Part 2 - the semi-volatile elements: $\mathrm{Cu}$, Mo, Ni and $\mathrm{Zn}$. Fuel 2009;88:961-9

|4| Bunt JR, Waanders FB. Trace element behaviour in the Sasol-lurgi MK IV FBDB gasifier. Part 2-The non- volatile elements: $\mathrm{Ba}, \mathrm{Co}, \mathrm{Cr}, \mathrm{Mn}$, and $\mathrm{V}$. Fuel 2010;89:537-48.

[5] Forney AJ, Haynes WP, Gasior SJ, Komosky RM, Schmidt CE, Sharkey AG. In: Environmental aspects of fuel conversion technology, vol. II; 1975. p. 67.

|6| Beishon DS, Hood J. Vlerath HE. In: Proceedings of the 6th international Pittsburgh coal conference; 1989. p. 539-47.

|7| Mahagaokar, U, Krewinghaus AB. Kiszka, MB. Shell Development Co. Jnterim Report to the Electric Power Research Institute, EPRI 65-7051. Project 2695-1; 1990.

|8| Helble J. Mojtahed W. lyyriinen J. Jokiniemi J. Kauppinen E. Trace element partitioning during coal gasification. Fuel 1996;75(8):931-9.

[9] Clarke l. Management of by-products from IGCC power generation. IEA Coal Research; 1991.

[10] Thompson D, Argent BB. Thermodynamic equilibrium study of trace element mobilisation under air blown gasification conditions. Fuel 2002;81:555-70.

[11] Diaz-Somoano M, Martinez-Tarazona MR. Trace element evaporation during coal gasification based on a thermodynamic equilibrium calculation approach. Fuel 2003;82:137-45.

[12] Treviño $\mathrm{M}$. Tecnología de gasificación integrada en ciclo combinado. Glcc Club Español de la Energia; 2003. p. 95 [in Spanish]

[13] Clarke L, Sloss L. Trace elements, London: IEA Coal Research; 1991. p. 111.

[14] Meij R. Trace element behavior in coal-fired power plants. Fuel Process Tech 1994;39:199-217.

[15] Querol X. Fernandez-Turiel JL, López-Soler A. Trace elements in coal and their behaviour during combustion in a large power station. Fuel 1995:74(3):331-43.

[16] Clemens AH, Damiano LF, Gong D. Matheson TW. Partitioning behaviour of some toxic volatile elements during stoker and fluidised bed combustion of alkaline sub-bituminous coal. Fuel 1999;78(12):1379-85

[17] Furimsky E. Characterization of trace element emissions from coal combustion by equilibrium calculations. Fuel Process Technol 2000;63:29-44.

[18] Seames WS, Wendt J. Partitioning of arsenic, selenium, and cadmium during the combustion of Pittsburgh and Illinois a6 coals in a self-sustained combustor. Fuel Process Technol 2000:63:179-96.

[19] Yang R. Gauthier D. Flamant G. Volatility and chemistry of trace elements in coal combustor. Fuel 2001;80:2217-26.

[20] Miller BB. Kandiyoti R. Dugwell DR. Trace element emissions from cocombustion of secondary fuels with coal: a comparison of bench-scale experimental data with predictions of a thermodynamic equilibrium model. Energy Fuels 2002;16:956-63.

[21] Font 0 , Querol X, Plana F, Burgos S, García-Peña F. Condensing species from flue gas in Puertollano gasification power plant, Spain. Fuel 2006;85:2229-42.

[22] Font 0 . Trace elements in Integrated Gasification Combined Cycle fly ash: extraction of potentially valuable elements. $\mathrm{PHD}$ report. Polyteclunical University of Catalunya; 2007.

[23] Alastuey A, Jimenez A. Plana F, Querol X. Suárez-Ruiz ]. Geochemistry, mineralogy, and technological properties of the main Stephanian (Carboniferous) coal seams from the Puertollano Basin, Spain. Int J Coal Geol $2000 ; 45(4): 247-65$

[24] Thompson M, Walsh JN. New York, USA: Chapman and Hall, Inc; 1989.

[25] Clakkrabarti JN. Methods of determining clilorine in different states of combination in coal. In: Karr Jr C, editor. Analytical methods for coal and coal products, vol. l. New York: Academic Press; 1978, p. 323-45.

[26] Sager M. Rapid determination of fluorine in solid samples. Monatshefte fü Chemie 1987;118:5-29.

[27] Pougnet MAB, Orren M]. The determination of boron by inductively coupled plasma atomic emission spectroscopy. Part 2. Applications to South African environmental samples. Int J Environ Anal Chem 1986;24:253-65.

[28] Gordon GE. Zoller WH. Normalization and interpretation of atmospheric trace element concentration patterns. Proceeding of the 1st Annual NSF Trace Contaminants Conference. Oak Ridge. Tenn: Oak Ridge National Laboratory. CONF-73080; 1973. p. 314-25.

[29] Avarez-Ayuso E, Querol X, Tomas A. Environmental impact of a coal combustion-desulphurisation plant: abatement capacity of desulpluurisation process and environmental characterisation of combustion by-products. Chemosphere 2006:65:2009-17.

[30] Yudovich YE, Ketris MP. Valuable Trace Elements in Coal. Ekaterinburg 2006:538 [in Russian].

[31] Jiménez A. Martinez-Talazona R, Suárez-Ruiz ]. Paleoenvironmental conditions of Puertollano coals (Spain): petrological and geochemical study. Int J Coal Geol 1999;41:189-211. 
[32] Álvarez-Rodríguez R. Clemente-Jul C. Martín-Rubí JA. Behaviour of the elements introduced with the fuels in their distribution and immobilization between the coal-petroleum coke IGCC solid products. Fuel 2007;86:2081-9.

[33] Font 0 , Querol $\mathrm{X}$, Huggins $\mathrm{FE}$, Chimenos JM, Fernández Al, Burgos $\mathrm{S}$, et al Speciation of major and selected trace elements in IGCC fly ash. Fuel $2005 ; 84: 1364-71$

[34] Font 0 , Querol $X$, López-Soler $A$, Chimenos JM, Fernández AlS, García Peña $F$ et al. Ge extraction from gasification fly ash. Fuel 2005;84:1384-92.

[35] Moreno $N$, Querol X, Andrés JM, Stanton $K$, Towler $M$, Nugteren $H$, et al Physico-chemical characteristics of European pulverized coal combustion fly ashes. Fuel 2005:84:1351-63.

[36] Meij R, Winkel HTe. Mercury emissions from coal-fired power stations: the current state of the art in the Netherlands. Sci Tot Environ 2006;368:393-6.

[37] Handbook of Chemistry and Physics. Properties of the Elements and Inorganic Compounds, Section 4, 90th Ed. Internet version; 2010
|38| Vassilev SV, Eskenazy GM, Vassileva CG. Contents, modes of occurrence and behaviour of chlorine and bromine in combustion wastes from coal-fired power stations. Fuel 2000:79:923-37.

[39] Reed GP, Erguèdenlerb A, Gracec JR, Watkinsonc AP, Heroda AA, Dugwell D, et al. Control of gasifier mercury emissions in a hot gas filter: the effect of temperature. Fuel 2001;80(5):623-34.

[40] Boyd R]. The partitioning behaviour of boron from toumaline during ashing of coal. Int J Coal Geol 2002;53:43-54.

[41] Font 0 , Izquierdo $M$, Alvarez $E$, Moreno $N$, Diez $S$, Querol $X$, Otero $P$, BallesterosjC. Giménez. A. Effect of the addition of pet-coke on the partitioning of trace elements in pulverised coal combustion ( $\mathrm{PCC}$ ) plants. In: Proceedings of the 2 nd World of coal ash conference (WOCA), 2007, May 710th. Cincinnati, Kentucly. USA. 